\title{
Shallow waters: social science research in South Africa's marine environment
}

\author{
M. Sowman, D. Scott, L.J.F. Green, M.M. Hara, M. Hauck, K. Kirsten, B. Paterson, S. \\ Raemaekers, K. Jones, J. Sunde and J.K. Turpie
}

\begin{abstract}
This paper provides an overview of social science research in the marine environment of South Africa for the period 1994-2012. A bibliography based on a review of relevant literature and social science projects funded under the SEAChange programme of the South African Network for Coastal and Oceanic Research (SANCOR) was used to identify nine main themes that capture the knowledge generated in the marine social science field. Within these themes, a wide diversity of topics has been explored, covering a wide geographic area. The review suggests that there has been a steady increase in social science research activities and outputs over the past 18 years, with a marked increase in postgraduate dissertations in this field. The SEAChange programme has contributed to enhancing understanding of certain issues and social interactions in the marine environment but this work is limited. Furthermore, there has been limited dissemination of these research results amongst the broader marine science community and incorporation of this information into policy and management decisions has also been limited. However, marine scientists are increasingly recognising the importance of taking a more holistic and integrated approach to management, and are encouraging further social science research, as well as interdisciplinary research across the natural and social sciences. Possible reasons for the lack of communication and coordination amongst natural and social scientists, as well as the limited uptake of research results in policy and management decisions, are discussed and recommendations are proposed.
\end{abstract}

\section{Introduction}

In the early part of the 2oth century, marine science in South Africa was purely a natural science pursuit, dominated by physical oceanography. As a research area, marine science became more diversified throughout the century but remained a natural science domain producing knowledge in the disciplines of physical oceanography, biology, zoology, chemistry and others within the traditional paradigm of science, producing Mode 1 knowledge $^{1}$ (Gibbons et al. 1994, Nowotny et al. 2001, Harriss 2002). Traditional Mode 1 knowledge production is known as 'formal science' (Hajer 1995), which has its own set of procedures for affirming 'sound science', namely peer review, independence, objectivity

\footnotetext{
${ }^{1}$ Mode 1 knowledge production assumes that scientists operate in an apolitical space, with the aim of being free from societal values and producing objective 'true' knowledge (Tovey 2008)
} 
and transparency (Tovey 2008, p 188). It was only at the end of the century that the first social science contributions to research in the marine environment in South Africa began to appear.

In the context of international isolation during apartheid, a suite of marine science national programmes was established in the early 1980 os and administered by SANCOR ${ }^{2}$. These large programmes involved teams of multidisciplinary marine science researchers and it was within these programmes that the need for social science 3 research in the marine and coastal environment was first considered. South Africa's recognition of the importance of social science research was also influenced by shifts in thinking globally regarding information requirements for, and approaches to, management of coastal and fisheries resources (Cincin-Sain and Knecht 1998, Berkes et al. 2001, FAO 2003, 2009, Garcia et al. 2008). First, there was a shift from disciplinary to interdisciplinary and transdisciplinary research (Max-Neef 2005), which recognised that collaborative research across disciplines is needed to solve complex environmental and social problems (Berkes et al. 2001, Charles 2001); second, there was an increasing realisation that marine resource manage ment is about managing the interactions between humans and the environment and addressing the social objectives (Berkes et al. 2003, Christie et al. 2003); third, there was a recognition that government cannot be solely responsible for marine resource management and requires involvement of non-state actors (Hajer and Wagenaar 2003, Kooiman et al. 2005); fourth, the necessity to recognise and include different knowledge sources in management decisions was itself increasingly recognised (Berkes et al. 2001, 2003, Garcia et al. 2008, FAO 2009). In addition, there was a recognition that research was needed to produce knowledge that meets the needs of South Africa's national goals of social redress, redistribution and equitable access to resources.

Early social science research in South Africa was ad hoc and it was only once the SANCORmanaged programmes - Sea and Coast $\mathrm{l}$ and $\mathrm{ll}$ - were established in 1995 that social science research was explicitly included in the content of such programmes. However, given the limited involvement of social scientists in the Sea and Coast programmes, the SEAChange programme, launched in 2006, explicitly included a theme for social science, entitled 'Ecosystems and Society', with a stated commitment to involve more social scientists in marine research. The title of the programme, 'Society, Ecosystems and Change' (SEAChange), in fact reflects both a significant shift in the content of the programme towards an ecosystem approach and inclusion of a societal context in the framing of the programme. A key focus of this new programme was to enhance understanding of the dynamic interactions between society and marine ecosystems. Four thrusts were identified to encourage a more holistic and interdisciplinary and transdisciplinary approach to marine science research. These were: (1) Ecosystems and

\footnotetext{
${ }^{2}$ SANCOR was originally established in 1956 as the South African National Committee on Oceanographic Research (Lutjeharms and Shannon 1997, Krige and Morrell 2007). In 1993 a new body was formed, the South African Network for Coastal and Oceanic Research, but the acronym was retained (Schnetler 1993)

${ }^{3}$ The term 'social science' used here refers to the broader set of non-natural science fi elds of knowledge production which include the humanities, law, economics, planning and engineering
} 
Change, (2) Ecosystems and Society, (3) Ecosystem Functioning and (4) Marine Biotechnology.

This paper aims to provide a review of social science research in the marine environment since 1994, with a particular focus on social science research funded under the SEAChange programme. It also aims to identify the key thematic areas emerging in this field, the state of knowledge in selected themes and possible knowledge gaps, as well as to explore some of the challenges facing social scientists working in the marine research environment.

\section{Methods}

While the initial focus of this review paper was on social science projects funded under the SEAChange programme, it soon became evident that there were relatively few social science projects funded under this programme between 2006 and 2011, and that a broader approach to the review was required. Consequently, it was agreed by the Programme Management Committee of SANCOR that the ambit of the review would be expanded to include social science research in the marine environment more generally, spanning the period 1994-2012. The focus would be on academic outputs, namely published papers and student dissertations, although selected social science research reports would also be included.

In order to identify key research themes, the first task was to undertake a review of published papers and student dissertations in the general field of societal interactions in the marine environment. This initial review was developed from an existing database located at the Environmental Evaluation Unit, University of Cape Town. Additional references were then identified through expanded searches and a draft bibliography ${ }^{4}$ was compiled. This draft bibliography was used to identify the main social science thematic areas. The lead researchers 5 involved in research in a particular theme were then invited to participate in the review exercise by providing a review of the state of knowledge of their particular theme as well as assisting with expanding the bibliography. They were also asked to respond to a set of questions that probed their area of expertise and the challenges they face as social scientists working in the marine science field, and to make recommendations. Reviews of other relevant reports on the state of marine science in South Africa, such as Gibbons (2009) and Scherman et al. (2011), as well as a review of the tables of contents of the African Journal of Marine Science (previously the South African Journal of Marine Science) for the period 1990-2011, were also undertaken to ascertain the extent to which social science research in the marine environment has been incorporated and reported on in the publications read by the marine science community in South Africa.

The nine thematic areas, including the SEAChange social science projects, are listed below: 1. Coastal development and tourism

\footnotetext{
${ }^{4}$ The complete bibliography is available from the EEU, UCT

${ }^{5}$ Not all researchers invited to participate in this paper writing exercise responded to this call and some were not available at the time
} 
2. Economic analysis of coastal and marine ecosystems

3. Transformation of the fishing industry

4. Coastal fishing communities - characteristics, issues and impacts

5. Governance of coastal and fishery systems

6. Human dimensions of an ecosystem approach to fisheries (EAF)

7. Human dimensions of marine protected areas (MPAs) (SEAChange project)

8. Coastal access (SEAChange project)

9. Working with fishers' knowledge (SEAChange project)

\section{Main thematic areas}

In this section we provide a brief overview of the nature of research undertaken in the thematic areas, and highlight some of the key findings and gaps in knowledge.

\section{Coastal development and tourism}

Approximately $40 \%$ of the country's population live within $100 \mathrm{~km}$ of the coast, with the greatest proportion concentrated at port cities such as Cape Town, Port Elizabeth, East London, Durban and Richards Bay (Palmer et al. 2011). The legacy of ad hoc, uncoordinated and racially-based planning and development in South Africa has resulted in ribbon development, ecological degradation due to inappropriate land-use practices and developments in sensitive ecosystems, loss of access to coastal areas and resources, and conflicts amongst competing stakeholders (Hauck and Sowman 2001, Glavovic 2006a, Glavovic and Cullinan 2009, Blair 2011, Kirkby 2011).

Sustainable development of the coast is therefore one of the biggest challenges facing coastal management and has been the subject of various papers considering the national context (Glavovic 2000, 2006a, 2006b). Colenbrander (2009) sought to understand the linkages between social and ecological systems in order to facilitate effective integrated coastal management (ICM). The coastal zone will always be a popular place for people to live, work and play; developments range from large resorts, gated estates, ports and harbours to pro-poor ecotourism ventures. Ahmed $(2008,2010)$ recognised the contested nature of coastal spaces in Africa, focusing on development pressures shaping the KwaZulu-Natal (KZN) coastline. Preston-Whyte and Oelofse (2007) considered the drivers and management implications of coastal resort development on South Africa's coast while van Wyk (2007) analysed the planning approach to development and environmental impacts of the illegal cottages along the Transkei Coast. Also in the Eastern Cape, Palmer et al. (2010, 2011) examined coastal development, land use change and drivers thereof, while Mitchell et al. (2008) examined the impact of the Wild Coast Spatial Development Initiative on local communities.

At the project level, environmental decision-making tools, such as environmental impact assessment (EIA), social impact assessment (SIA) and strategic environmental assessment (SEA), have been employed to guide coastal planning. Researchers interrogated the effectiveness of EIA processes linked to coastal development including the controversial proposed mining development near St Lucia (Kruger et al. 1997) and golf 
estates on the Cape south coast (Kirkby 2011). In general, these studies highlighted various inadequacies in the EIA process, including the general neglect of social and cultural issues and impacts. Furthermore, opportunities for participation, especially of marginalised communities, were found to be inadequate. Site-specific EIAs fail to take a broad, holistic approach to coastal development and management, thereby undermining the goals and principles of the White Paper for Sustainable Coastal Development (DEAT 2000). Celliers et al. (2004) and Clark (2004) employed SEA as a tool to examine recreational areas for off-road vehicles (ORVs) in KZN and nationally, in order to avoid ad hoc zoning applications in areas that might be environmentally or socially unsuitable.

The beach is often a place of tourism and recreation and a number of social studies focusing on beach leisure have been undertaken (De Ruyck et al. 1995, 1998, Prochazka and Kruger 2001, Turpie and de Wet 2009). Although these authors largely sought to document and understand recreational trends in beach environments, some also considered how such information could inform beach management and planning.

Other social scientists have focused on trying to understand recreational patterns and trends in the context of political change post-apartheid (Mwandla 1995, Durrheim and Dixon 2001, Hemson 2001, Preston-Whyte 2001, 2002, Thompson 2011). As an example, Preston-Whyte (2001) documented the division of recreational activities along the coast and explored how such spaces are characterised by group identities and cultural dominance. He concluded that an understanding of how constructed leisure spaces are conceptualised should inform management (Preston-Whyte 2001, p 582). These shoreline recreational studies assist in the identification of existing and future impacts and provide a deeper understanding of the dynamics at play - knowledge which could be applied to enhance management practices and decisions.

Tourism development is considered to be one of the main drivers of coastal change and is often seen as the panacea for rural coastal communities (Koch et al. 1998, Govender et al. 2005, Glavovic and Boonzaier 2007, Ntonzima and Binza 2011). This has been a popular topic for research amongst geographers. Tourism as a mechanism for poverty alleviation and local economic development (LED) in coastal areas has been investigated by a number of researchers in addition to those above (Kepe 2001, Nel and Binns 2002, Cousins and Kepe 2004, Mograbi and Rogerson 2007, Chellan and Khan 2008, Saayman et al. 2009, Mbatha 2011) with the main interest being to establish sustainable initiatives. Most of these studies have focused on the previous coastal 'homelands' of the Eastern Cape and KZN, which are in urgent need of economic development and offer potential for tourism due to natural attributes and relatively unspoilt coastlines. However, in reality these projects do not often produce the benefits that are promised. The most common challenge is that of weak governance to support such initiatives, i.e. institutional failings - in particular the lack of integration and cooperation between stakeholders - and lack of capacity within government (Govender et al. 2005, Ntonzima and Binza 2011). Despite varying success, there seems to be a common sentiment that if certain conditions are met, tourism has the potential to 
improve the quality of life of coastal communities. Factors that facilitate sustainable tourism seem to be an emerging area of interest and further work in this field will contribute to more effective planning and management of tourism initiatives in the context of rural development and poverty alleviation.

A number of ecotourism initiatives have relied on marine resources specifically and various papers have considered the implications of these initiatives for resources, MPAs and local communities. Initiatives include tourism based on the sardine run (Myeza 2007, Dicken 2010, Myeza et al. 2010), whale watching (Findlay 1997, Turpie et al. 2005) and penguin viewing (Morgan 1996).

Ports have also been a focal theme of social research with Durban and Cape Town being popular case studies. Durban's port has been studied in the context of port development, including the use and regeneration of adjacent precincts (Grant and Scott 1996, Jones 2002, Scott 2006, Scott and Oelofse 2007, Dray 2009). In general, the findings highlight the contested nature of such spaces, as economic agendas reshape urban form, often marginalising smaller user groups. Similarly, the redevelopment of the Victoria and Alfred Waterfront in the port of Cape Town has been the focus of a number of social science studies (Kilian 1994, Worden 1994, Goudie et al. 1995, Kilian and Dodson 1995, 1996a, 1996b, Worden 1996, Dodson and Kilian 1998, Ferreira and Visser 2007). These studies mostly sought to understand the implications of tourism development and commercialisation in the context of economic development and local maritime activities. The finding in most instances was that a 'more socially informed planning' was called for (Kilian and Dodson 1996a, p 506).

Social science research in relation to coastal mining has not yet received much attention. In KZN, several studies focusing on Richards Bay Minerals have been undertaken. These have explored issues of access and benefit sharing in relation to local rural communities (Jaumain 2009, Mbatha 2011) and examined the real or perceived success of corporate social responsibility initiatives in uplifting poor neighbouring coastal communities (Kapelus 2002). Apart from Blair (2011), Namaqualand has been largely neglected by the social science community, with independent studies investigating the impacts of mining and decommissioning.

The coast, as the interface between sea and land, offers opportunities for property development, recreation, tourism, livelihoods, trade and industry. There is considerable demand on coastal property and resources by competing sectors and resource users, with development patterns mostly shaped by economic forces. Residential property and tourism development usually offer the highest returns and recent development trends along the coast are evidence of this (Scott and Sowman 2012). Research in this area is limited to specific cases and few studies provide an overall analysis of the contributions and impacts of coastal development that could inform a more strategic approach to planning and decision-making. 


\section{Economic analysis of coastal and marine ecosystems}

Understanding the value of coastal and marine ecosystems, as well as the economic forces leading to their degradation, is essential to achieving sustainable development in the coastal zone. Research on coastal values started in South Africa in the late 1990s, with a study by McGrath et al. (1997) on the value of South Africa's inshore line fisheries. In other early studies, McCarthy et al. 1998 produced a rough estimate of the economic value of the South African coast for the Coastal White Paper (DEAT 2000), and Turpie et al. (2003) quantified the value of the coast of the Cape Floristic Region.

Several valuation studies have been undertaken on estuaries. These included a detailed analysis by Lamberth and Turpie (2003) on the economic contribution of estuaries to estuarine fisheries. Other studies of the value of individual estuaries (e.g. Cooper et al. 2003, Sale 2005), or activities within them (Napier et al. 2009), were collated into a workshop proceedings (Turpie and Hosking 2005). Data available at that time were then collated and augmented in a study which estimated the total economic value (including direct, indirect and non-use values) of each of South Africa's 289 estuaries (Turpie and Clark 2007). This information was used to develop an integrated conservation plan for South Africa's temperate estuaries under the Cape Action for People and the Environment [C.A.P.E.] programme (Turpie and Clark 2007).

Water use is one of the most important trade-offs involved in estuary conservation. Several authors (e.g. Hosking et al. 2002, Sale 2005) have conducted contingent valuation studies of a number of South African estuaries in order to value users' willingness to pay for water to maintain a stated level of biodiversity in these systems. More recently, the approach to understanding these trade-offs has been improved using ecological-economic modelling (Turpie et al. 2009) and choice experiment techniques to examine the impacts of changes in estuary characteristics on their value (Lee 2012).

The 2000s saw a lot of scientific and political attention on fisheries management and MPAs. Several studies described the socio-economic characteristics and values of smallscale commercial fisheries (Griffiths and Lamberth 2002, Hutchings et al. 2002, Mather et al. 2003). Cochrane (2000) and Crosoer et al. (2006) investigated broader questions about the economic role of South Africa's commercial fisheries, while Daniels (2001, 2002) examined the impact of subsistence fisheries on poverty alleviation. Economic analysis of fisheries has started to change course in line with a global trend towards behavioural and experimental economics, with an increasing tendency to try and understand the choices and compliance behaviour of fishers in order to inform more strategic management (Brick et al. 2012).

An economic study of the MPAs of the Garden Route coast in the South-Western Cape found that they added substantial value compared with unprotected coastal areas, and that the value of no-take protection outweighed the opportunity costs (Turpie et al. 2007). However, accurate valuation of the fish export function of MPAs is still hampered by a 
paucity of ecological data, and the social and cultural dimensions of such analyses are limited by a paucity of social data.

Numerous studies have been conducted on the recreational value of coastal activities including ecotourism (see previous section), beach recreation (Ballance et al. 2000, Turpie and de Wet 2009) and recreational fishing (e.g. Brouwer et al. 1997, Cockcroft and Mackenzie 1997, Mann et al. 2002, Dicken et al. 2006, Leibold and van Zyl 2007, Beckley et al. 2008, Mann et al. 2012). Recreational value trade-offs are still poorly understood, however.

In general, studies on the value of coastal and marine ecosystems started with once-off estimates of value and have evolved to analysing the determinants of value and behaviour, the trade-offs involved in management decisions. With the introduction of the National Environmental Management: Integrated Coastal Management Act (RSA 2009), demand for economic research has increased, and further research of this nature will be essential to ensure that conservation and development decisions are well informed (Heal et al. 2005, Barbier 2012).

\section{Transformation of the fishing industry}

Following the democratic elections in 1994 and the promulgation of the Marine Fisheries Policy (DEAT 1997) and soon thereafter the Marine Living Resources Act (MLRA; RSA 1998), there were great expectations that the new legislation would lead to significant transformation and restructuring of the fishing industry and enhanced access to marine resources for coastal fishing communities. Various scholars, both from within and outside of the country, were fascinated by the transformation process unfolding in South Africa and several studies were undertaken that examined various aspects of it (Hersoug and Holm 2000, Isaacs 2001, Hersoug 2002, van Sittert 2002, 2003, Isaacs 2003, Kleinschmidt et al. 2003, Branch and Clark 2006, Crosoer et al. 2006, Isaacs 2006, Hauck and Kroese 2006, Raakjær Nielsen and Hara 2006, Sowman 2006, van Sittert et al. 2006, Witbooi 2006, Ponte and van Sittert 2007, Hara and Raakjær 2009). Several of these papers appeared in a special edition in Marine Policy (volume 30(1) 2006), which aimed to provide a review and analysis of fisheries reform after 10 years of democracy. A key focus of this work was investigating the extent to which objectives of redress, equity and socio-economic development had been addressed in practice.

The new fisheries dispensation, especially the introduction of medium-term rights (2002 to 2005) and later long-term rights (from 2006 to 2020) (DEAT 2001, 2005), reflects government's macro-economic policy shift from the Reconstruction and Development Programme (RDP) to the Growth Employment and Redistribution Strategy (GEAR) (RSA 1996). According to government, policy alignment to GEAR aims to achieve equity and redistribution through growth of the fishing economy. Redistributive transformation is to be achieved through a number of avenues including: the transfer of fishing rights to the historically disadvantaged; increased black shareholdings in fishing companies; increased gender representation in managerial and directorship positions; broad-based black 
economic empowerment (BBBEE)66; and improving the quality of employment for workers.

According to the medium-term reviews (DEAT 2004), as well as the long-term rights interim performance reviews (DAFF 2012a), transformation is moving in the right direction; black ownership (rights), black shareholding and black directorships are all more than 50\%. The industry remains male-dominated, though, in terms of rights and directorships. However, researchers are more critical of the transformation process, claiming that capital and infrastructure largely remain in the hands of original established rights holders (Raakjær Nielsen and Hara 2006, Isaacs et al. 2007, Ponte and van Sittert 2007). The practices of 'fronting' and 'paper quota holding' remain rife and within companies it is not easy to know 'who owns who' and 'who owns what' (Raakjær Nielsen and Hara 2006). New labour saving technologies are resulting in increased loss of and casualisation of employment. Thus, while many acknowledge that progress has been made in transforming the face of the fishing industry post-1994 (Hersoug 2002, Raakjær Nielsen and Hara 2006, van Sittert et al. 2006, Ponte and van Sittert 2007), this has been at the expense of improving access and restoring rights to marine resources for margin- alised coastal communities (Isaacs 2006, Sowman 2006, Isaacs et al. 2007, Isaacs 2011, 2012, Sowman et al. 2012, Sunde et al. 2013).

\section{Coastal fishing communities - characteristics, issues and impacts}

All along the South African coastline, men, women and children living in coastal communities have historically harvested a range of marine resources for their basic subsistence and livelihoods (van Sittert 1993a, 1993b, Branch et al. 2002a, Clark et al. 2002, Cardoso et al. 2005, MDT 2010, Sowman and Cardoso 2010, Sowman et al. 2011a). Prior to 2000, the distinctive characteristics of coastal fishing communities were relatively unexplored in published social science literature. The recognition of subsistence fishers as a separate category of fishers in the MLRA prompted a wave of research to better understand this sector (Branch et al. 2002a). In 2000, under the auspices of the Subsistence Fisheries Task Group (SFTG 2000), a national survey of coastal fishing communities was undertaken along the entire coastline in order to better understand the socio-economic characteristics and marine resource use associated with these communities. The findings of this survey were published in the SFTG report (SFTG 2000) as well as a series of journal articles (Branch et al. 2002b, Clark et al. 2002, Harris et al. 2002a, 2002b, Hauck et al. 2002). This work was elaborated on for the west coast of South Africa in a series of reports on small-scale fishers of the Benguela Current region (Cardoso et al. 2005, Sowman et al. 2011a). A key finding of this research has been the recognition that the MLRA 'subsistence' category was too narrowly defined as it failed to recognise the range of small-scale fishing activities that take place along the coast.

\footnotetext{
${ }^{6}$ Government defi nes BBBEE as 'an integrated and coherent socio-economic process that directly contributes to the economic transformation of South Africa and brings about signifi cant increases in the numbers of black people that own, manage and control the country's economy, in order to decrease income inequalities' (RSA 2003, p 12)
} 
Recent research by a number of postgraduate students working in coastal settlements across South Africa has provided further understanding of this small-scale fisheries sector (Hauck 2009a, Jaumain 2009, Kemp et al. 2009, Raemaekers 2009, Shanyengange 2009, Schultz 2010, Mbatha 2011, Rogerson 2011, Crowe 2012, Van der Krogt 2012). Small-scale coastal fisheries in South Africa vary dramatically from the West to the East coasts in terms of target species, gear, and the role of fishing within the social and livelihood context of coastal communities. The exploitation of marine resources for commercial purposes has dominated the histories of many of the communities living along the west coast of the country (van Sittert 1993a, 1993b, 2002, 2003, Bavinck et al. in press). In this region, small-scale fishing is predominantly boat-based and the fishing activities are labour-intensive. In contrast, many of the communities along the East Coast use marine resources as one of several livelihood options (MDT 2010, Sunde et al. 2013). Small-scale fishing activity along the East Coast is exclusively shore-based. A clear gender-based division of labour is observed in the sector, with men dominating in the harvesting of fish whilst women are predominantly involved in the harvesting of intertidal resources and in pre- and post-harvest activities (Branch et al. 2002b, Cardoso et al. 2005, MDT 2010).

Throughout South Africa, small-scale fishing communities are characterised by high levels of poverty and unemployment, with few opportunities to earn an income outside of fishing, poor infrastructure, limited access to services, and a range of social problems that are associated with these conditions (Branch et al. 2002b, Cardoso et al. 2005, Glavovic and Boonzaier 2007, Isaacs et al. 2007, Sowman et al. 2008, 2012, Isaacs 2011, 2012). Studies exploring drivers of change impacting coastal communities have looked at a range of issues including, amongst others, the impact of conservation, land and spatial planning initiatives (Fassen and Watts 2007, Sunde and Isaacs 2008), conservation, mining and tourism development (Jaumain 2009, Blair 2011, Mbatha 2011), HIV/AIDS (Isaacs and Hara 2008) and climate change (van Zyl 2009, Duggan 2012).

During apartheid many communities in South Africa were dispossessed both of their lands adjacent to the coast and some or all of their traditional fishing rights to harvest marine resources (van Sittert 1993a, 1993b, 2002, 2003, Sunde and Isaacs 2008, Sowman et al. 2011b). This history of marginalisation has impacted the level of information that is available about this sector. However, over the past 12 years there has been a significant growth in research in this thematic area. Furthermore, a move towards a more interdisciplinary and transdisciplinary focus within the social sciences over the past decade has given visibility to communities' cultural and ecological histories and practices (Fassen and Watts 2007, van Zyl 2008, 2009, Dennis 2010, Schultz 2010, Sunde et al. 2013). This information is necessary to inform appropriate governance and management arrangements and decisions in this sector.

\section{Governance of coastal and fishery systems}

Research on various aspects of small-scale fisheries governance became a key focus of attention with the country's transition to democracy in 1994. This interest was also 
linked to broader debates occurring worldwide regarding the appropriateness of applying conventional fisheries management approaches to the small-scale fisheries sector (Berkes et al. 2001, 2003, Garcia et al. 2008). A key message emanating from this literature was a realisation that alternative governance approaches were required to respond to the complex, diverse and often vulnerable conditions prevalent in these complex socio-ecological systems (Berkes et al. 2001, Charles 2001, Kooiman et al. 2005).

By the mid-1990s, researchers in South Africa were involved in various co-management projects and documented co-management processes and lessons learned to improve practice (Sowman et al. 1997, Hutton and Pitcher 1998, Hauck 1999a, 1999b, Hauck and Sowman 2001, Harris et al. 2003, Sowman 2003). Given the legislative requirements for greater public participation in decision-making, as well as the SFTG recommendations (Harris et al. 2002b, Hauck and Sowman 2003a), co-management became the core focus of several studies at both a theoretical and empirical level (Harris et al. 2003, Hauck and Hector 2003, Hauck and Sowman 2003b, Kyle 2003, Mann et al. 2003, Napier et al. 2005, Harris et al. 2007, Schell 2011). However, research on comanagement suggests that, in general, the practice of co-management has not achieved the objectives and outcomes envisaged (Sowman et al. 2003, Sunde and Isaacs 2008, van Zyl 2008, Hauck 2009a, 2009b, Raemaekers 2009, Sowman 2011), although comanagement has been implemented in 26 subsistence fisheries in KwaZulu-Natal and has achieved a measure of success (Harris et al. 2003, 2007, Napier et al. 2005).

A key finding from this research suggests that small-scale fishers are not adequately recognised and protected, nor are they adequately involved in fisheries management decisions that affect their lives. The barriers to greater involvement of fishers in decisionmaking revolve around institutional changes within the fisheries agencies and lack of capacity to implement co-management, lack of understanding of the principles and approaches underlying co-management, failure to allocate rights to small-scale fishers, and promised benefits of co-management not outweighing the costs (Sowman et al. 2003, Hauck 2009a, Sowman et al. 2008, Isaacs 2011, Schell 2011). Furthermore, coordinated government support for initiatives that identify and develop supplemental and/or alternative livelihoods in poor and resource-stressed areas is lacking (Mbatha 2011).

Within the theme of governance, significant research has been conducted on small-scale fisheries compliance. Under the Sea and Coast II programme one such project was funded (2005-2007) that aimed to develop and apply a conceptual framework for understanding and addressing non-compliance of small-scale fisheries in South Africa. This research project demonstrated that socio-economic and political factors are key drivers of noncompliance in South Africa, often leading to the criminalisation of small-scale fishers (Hauck and Sweijd 1999, Hauck 2007, Omari 2007, Hauck 2008, 2009a, 2009b). In some cases, such as the abalone fishery, governance challenges are exacerbated by an organised illegal fishery (Hauck and Sweijd 1999, Hauck 2009b, Raemaekers and Britz 2009, Raemaekers et al. 2011). Nevertheless, a key conclusion of this research, which is 
affirmed by other international studies, is that traditional crime control strategies are increasingly being questioned as an appropriate strategy to address resource overexploitation (Hatcher et al. 2000, Gezelius 2003, Raakjær Nielsen 2003). There is a need to rethink understanding of small-scale fisheries compliance (Hauck 2009a, 2009b, Gezelius and Hauck 2011) and recognise that social justice, legitimacy and deterrence are preconditions for understanding and addressing compliance in a more integrated manner (Hauck 2011).

\section{Human dimensions of an ecosystem approach to fisheries (EAF)}

The ecosystem approach to fisheries (EAF) is a new research and management paradigm, which has emerged as a response to the failure to manage the world's fisheries in a sustainable manner (FAO 2003). This approach considers fisheries as complex social and ecological systems and is often conceptualised in terms of three overarching objectives of fisheries management, i.e. ecological wellbeing, human wellbeing and good governance. However, traditionally the knowledge production to underpin fisheries management has focused on natural science. Thus, apart from selected FAO documents (De Young et al. 2008, FAO 2009), there is little guidance on how to manage fisheries for human wellbeing. Nonetheless there is a growing knowledge base in South Africa, and the two previous sections of this paper detail research relating to coastal communities and governance of coastal resource use. Objectives and indicators for human wellbeing have been developed for key industrial fisheries in South Africa (Jayiya et al. 2008, Paterson et al. 2010) and the Benguela Current region (Paterson and Petersen 2010). The latter work has grown out of numerous risk assessment workshops that utilised the categories of ecological and human wellbeing and good governance to identify and address social and economic issues of key South African fisheries ( Nel et al. 2007, Paterson and Petersen 2010). Sauer et al. (2003) collated snapshot socioeconomic information for key South African commercial fisheries. Prototype decision-support tools to measure both efficacy (Paterson et al. 2007, 2010) and implementation of EAF (Paterson and Petersen 2010) were developed for key fisheries in the region.

Recognising the interdependence between communities, industries and the biophysical environment, the Benguela Current Commission (BCC) in 2011 launched a project to develop agreement on what the notion of human dimensions of EAF means in the regional context and what knowledge is required to improve fisheries management (Paterson et al. 2012). Studies documenting the current state of knowledge on human dimensions of fishery systems were undertaken in Angola, Namibia and South Africa (Luyeye 2011, Russell 2011, Sowman et al. 2011a).

However, the notion of a 'human dimension' is misleading in its simplification, because it hides a complex web of a multitude of issues, themes and questions. The current dominant conceptualisation of EAF as having two distinct dimensions, one ecological and one human, serves to assign different areas of responsibility to natural and social scientists respectively. Researchers who have critiqued traditional fisheries science have pointed out that the current narrow focus on quantitative assessments of fish stocks requires

\section{http://repository.uwc.ac.za}


broadening and taking account of biological and ecological processes (e.g. Shannon et al. 2004). By the same token, it is clear that social and ecological changes and processes interact (e.g. Berkes et al. 2001, Ommer 2007, Murray et al. 2008). Consequently, the inclusion of the so-called 'human dimension' of EAF requires research that follows the processes through which people and fish are interconnected. This calls for combined social-ecological research and analyses, which demands that natural and social scientists work together, not separately.

\section{Human dimensions of marine protected areas (MPAs) (SEAChange project)}

Worldwide, MPAs are being employed as a key management tool to protect important coastal and marine resources and habitats, restore degraded habitats and rebuild overexploited fisheries resources (Mascia et al. 2010, FAO 2011). Increasingly, international literature and experience indicate that social factors, not ecological or physical variables, are the primary determinants of MPA success (Agardy 1994, Christie et al. 2003). This SEAChange-funded project aims to develop a conceptual framework and a set of guidelines for understanding and integrating human dimensions into the planning, assessment and management of MPAs in South Africa. Although there has been an increasing recognition amongst conservation and fisheries scientists and managers in South Africa of the need to address the human dimensions in MPA planning, they are grappling with how to do this. The target-driven approach to expand areas under marine protection without active involvement of resource users, especially poor and marginalised coastal communities, is alienating them from mainstream conservation efforts and promoting 'illegal' harvesting activities (Beaumont 1997, Sunde and Isaacs 2008, Hauck 2009a, 2009b, Sowman et al. 2011b, in press).

Based on a review of the literature, a conceptual framework was developed to clarify the term 'human dimensions' and guide case-specific research (Sowman et al. 2011c). Five postgraduate students are currently involved in research at various study sites in or adjacent to MPAs (or proposed MPAs) (Dwesa-Cwebe, Hluleka, Tsitsikamma, Struis Bay, Table Mountain National Park and Langebaan). The aim is to enhance understanding of the human dimensions of these MPAs and determine how this information can inform MPA planning and management.

Thus far, findings from the case studies reveal that despite South Africa's adoption of a host of international instruments relevant to 'people and protected areas', and national legislation requiring participation of local communities in decision-making, the identification, planning and management of MPAs in South Africa has been characterised by science-based and top-down decision-making. Inability to access food, especially in times of crisis, loss of livelihoods, alienation of fishers from their environment, loss of cultural identity and erosion of customary governance systems are all impacts associated with this approach to the declaration and management of MPAs (Sunde and Isaacs 2008, Sowman et al. in press). Another key objective of the project has been to better understand the nature of customary practices and governance systems 
in small-scale fisheries in Dwesa-Cwebe ${ }^{7}$ and Langebaan (Sunde et al. 2013) and consider how these systems can be accommodated alongside state systems, especially in view of the provisions in the new small-scale fisheries policy (DAFF 2012b). Recent efforts by a range of governance actors to adopt a more people-centred approach to MPA planning at the Olifants Estuary, Dwesa-Cwebe and Agulhas-Struis Bay are being monitored as part of this research. Based on research findings, as well as review of international best practice, a set of guidelines for integrating human dimensions into MPA planning and management is being developed.

\section{Coastal access (SEAChange project)}

An emerging area of research interest has been the exploration of how access to the coast has been reconfigured post-1994. The promulgation of a suite of new policies and laws, in particular the White Paper on Sustainable Coastal Development (DEAT 2000), indicated government's commitment to enhance and ensure equitable access to the coast. This has been given legal effect in the Integrated Coastal Management Act (ICMA; RSA 2009). A SEAChange-funded ${ }^{8}$ project (2008-2009) entitled 'Access to South Africa's coast post-1994' sought to enhance understanding of factors that constrain and enable access to the coast and ascertain whether policy objectives relevant to coastal access have been realised. Drawing on Ribot and Peluso's (2003) access framework, a number of coastal case studies were undertaken to investigate the factors that influence coastal access and how different stakeholders have been affected by land-use changes and decisions. Land-use changes, including development of golf estates and residential units (Kirkby 2011), expansion of conservation areas (S Williams, University of Cape Town, unpublished data), mining activities (Jaumain 2009, Blair 2011, Mbatha 2011) and land restitution (S Williams unpublished data), have consequently been investigated. Restrictions on beach access due to the ORV regulations promulgated in 2001 (RSA 2001), for example, have impacted recreational and commercial anglers frequenting remote beaches as well as the ski-boat fraternity (Fielding 2011).

A second aspect of this study was to obtain a broad overview of coastal access trends and associated drivers in each of the coastal provinces. It was found that policy and legal reforms post-1994, as well as external drivers such as international agreements, population increases and climate change, have all contributed to changes in coastal access. These studies highlighted the unique attributes of the four coastal provinces, including the natural resources and socio-economic characteristics as well as historic land uses, giving rise to a particular set of access trends. These findings have been synthesised by Scott and Sowman (2012) and detailed by Blair and Scott (2011), Northern Cape; Sunde (2011), Western Cape; Fielding (2011), Eastern Cape; and Scott (2011), KwaZulu-Natal.

\footnotetext{
${ }^{7}$ A recent court case, S vs Gongqose and Others E382/10 (not reported yet) highlights some of the fi ndings of this research

${ }^{8}$ Funding was also obtained from the South Africa-Nederlands Research Programme on Alternatives in Development [SANPAD] for the period 2009-2011 to expand the ambit of this project and include additional case studies
} 
Coastal development is prevalent in all coastal provinces, except the Northern Cape, and driven by various factors such as increasing tourism, foreign investment, value of coastal property, population growth and in-migration resulting in urban expansion, ribbon development and high-end gated estates (Scott and Sowman 2012). In some cases this has enhanced access as facilities and roads have been improved, whilst gated estates have had negative implications for access, particularly for poor communities and recreational users that utilise the coast (Kirkby 2011). The high value of agricultural land, mostly white-owned, is perpetuating spatial inequalities while industrial development and port expansion in the three provinces has resulted in a loss of access to the coast. Whilst protected area expansion has impacted physical access in some provinces, impacts on livelihoods, especially of resource-dependent communities, have been significant (refer the previous section). Legislative requirements to identify coastal public property and coastal access land have not yet been met and vast stretches of the coast remain inaccessible to the public, in some cases illegally. Coastal private nature reserves are becoming a more popular alternative to farming where land is less productive (Fielding 2011, Scott 2011, Sunde 2011). Mining in the Northern Cape has significantly restricted coastal access and although mining reform was expected to improve access, mining companies have been seeking alternative private ventures for the land (Blair 2011). Overall, private land ownership is the single most limiting factor to coastal access, especially where public servitudes between contiguous properties are lacking. These general findings, as well as the more specific findings emanating from the case study research, will be used to inform the development of a coastal access strategy for South Africa as required by the ICMA.

\section{Working with fishers' knowledge (SEAChange project)}

Fisher livelihoods in southern Africa have been profoundly affected by the Marine Living Resources Act (RSA 1998) and subsequent fisheries policies (van Sittert 2002, 2003, Hauck and Sowman 2003b, Cardoso et al. 2005, Isaacs 2006, Sowman 2006, Bohlin 2007, Isaacs et al. 2007, van Zyl 2008, Hara and Raakjær 2009, Schultz 2010). The combination of loss of livelihoods and limited consideration of fishers' knowledge contributes greatly to non-compliance (Hauck 2008, 2009a, 2009b). For this reason, finding ways to improve the dialogue between fishers and conservationists is important.

Research on fishers' knowledge in South Africa has not been a major focus until recently. Van Zyl's study (2008) found that, in the context of negotiations and polemical public discussions, people tended to intensify their positions and retreat into an identity politics of knowledge. The implication of her findings was that the tenor of the meetings themselves was contributing to the intractability of the dialogues. Where scientists and policymakers saw themselves as representing 'nature', fishers and fisheries activists increasingly offered the counter-argument of 'culture'. Later studies, several of which were funded by SEAChange (2010-2012), have sought to gain insight into the contests over the knowledge base of fisheries policy and management. Such research has been pursued in Kassiesbaai (van Zyl 2008, 2009), St Helena Bay (Schultz 2010), Kalk Bay (Anderson 2011), Lambert's Bay (Rogerson 2011), Still Bay (Duggan 2012) and Gans Bay (Ragaller 2012). 
An important finding of these studies was that the grounds for mediation of knowledge differences were more evident from detailed ethnographic and historical research than from documenting polemical public meetings. Researchers found that fishers assert a very detailed knowledge of marine ecosystems, and that long-term memory of patterns, cycles and environmental events were evident in everyday memory, and in skippers' logbooks and catch records.

The focus on knowledge differences produced several important observations. First, fishers' narratives of the ocean as a partner with whom they have a relationship may appear to be incompatible with a science that separates knowledge from belief; yet, for many, that relationship is an important basis for careful harvesting practices. Second, fishers' reliance on intuitive ways of knowing the ocean, such as recognising sea colour, is difficult to communicate where scientists ask for data based on enumeration. Third, different scales of reference - spatially and temporally - meant that people were often talking past one another. For example, a fisher might be thinking of the next meal; a politician might want immediate results; an ecologist may be concerned with 30- to 50-year cycles. Fourth, fish, too, might be understood differently: many fishers speak of the intelligence of fish, and do not see them as the unintelligent and unresponsive forms of life that appear in annual catch quotas. In short, what people understand to be 'nature' - whether ocean or fish - might differ greatly (Green 2012). Yet a fisher's 'ocean-as-partner' or 'fish-with-intelligence' perspective does not necessarily need to be 'converted' into a dialogue based on numbers in order to ensure their conservation. The partnership that many fishers describe when they speak of the sea and fish is a resource for conservation that has no price tag.

Moving towards a dialogue that draws on different ways of knowing the ocean (Whatmore 2009), several research projects have recently been concluded on the interaction of state, sciences and publics in the South African fishery (G Duggan, University of Cape Town, pers. comm.). Working with Still Bay fishers and scientists, Duggan found that many fishers work with very detailed temperature measurements, identify variations of particular species, and can speak to variations in annual temperature patterns and related changes in species' distributions (Duggan 2012). Rogerson's research in Lambert's Bay described the ways in which knowledge is a matter of embodied skill as much as it is a matter of language and numbers (Rogerson 2011). Ragaller (2012) focused on the integration of communications technology into fishing practice. Anderson (2011) worked with DAFF (Department of Agriculture, Forestry and Fisheries) officials and skippers in Kalk Bay to understand the ways in which logbooks serve as the interface of state, science and public - in particular looking at the kinds of knowledge translations and deletions at work in the databasing process. Such findings suggest that consultations between state, sciences and publics require careful consideration of knowledges and ways of knowing.

\section{Discussion}

\section{Wide-ranging and uncoordinated nature of social science research}

This review revealed that a wide range of themes and topics is being investigated by social scientists working in the marine environment. Although it was possible to

\section{http://repository.uwc.ac.za}


identify nine key thematic areas, the range of projects identified within some of these themes was wide-ranging and covered a vast geographic area. Papers range from those that are highly theoretical to those that are purely descriptive. From a geographical point of view, certain areas have attracted much attention, such as the Garden Route, the Durban beachfront and coastal conservation areas along the Eastern Cape and KZN coasts. Relatively little social science research has been conducted in the Northern Cape, for example, and this represents a knowledge gap.

While most projects fall within a particular discipline (e.g. economics, sociology, anthropology, law) or involve a number of disciplines within the social sciences (e.g. geography and social anthropology), few projects are truly interdisciplinary or transdisciplinary in nature and involve researchers from both the natural and social sciences. However, some of the recent SEAChange-funded projects, namely 'fisher knowledge' and 'human dimensions of MPAs', as well as recent work on EAF and research on valuing ecosystems, have been collaborative and interdisciplinary in nature. Given the increasing recognition of the complexity of coastal and marine socio-ecological systems and the need to take an holistic and systems-orientated approach to understanding and managing them, greater effort and resources should be invested in promoting interdisciplinary and transdisciplinary research in this arena.

In terms of the scope of the research, this review suggests that social science research in the marine environment has been driven largely by three factors. First, socio-political events, such as the promulgation of new legislation, have inspired research into topics such as the transformation of the fishing industry and coastal access; second, addressing gaps in knowledge, such as the need for information on subsistence fisheries identified in the MLRA, catalysed research in this arena; and third, development of new ideas and research interests in the international arena, such as economic valuation of ecosystem goods and services and the human dimensions of EAF, began to be explored in the South African context. In general, this review found that research themes tend to develop around senior researchers, or a group of researchers with a particular interest, who then involve a number of postgraduate students linked to funding. However, in many cases the research is limited to a particular university department and geographic area and there is limited collaboration across institutions in some thematic areas. This represents a lost opportunity in terms of building a substantial body of knowledge in a particular knowledge field.

Thus, research has been largely driven by socio-political events and research interests, rather than an overarching research strategy that identifies key knowledge areas requiring attention by social scientists. Although information needs emerge through engagement with the marine science community and government managers, there has to date been no review of social science research in the marine environment to assist with the development of such a strategy. This review may go some way towards providing the basis for discussions on such a research strategy. 


\section{Steady increase in social science projects and outputs}

A recent review of the status of marine science in South Africa over the period 19942008 (Scherman et al. 2011) found that, of the 9568 coastal and marine sciencerelated outputs identified, $4.4 \%$ were from the social sciences. The current review on the other hand, identified a total of 143 social science outputs for the period 1994present. However, while the overall total number of social science outputs is less than identified in the Scherman et al. (2011) review, it needs to be noted that the focus of the current review was on postgraduate student dissertations (excluding honours dissertations) and published papers and only included key research reports that contributing authors felt were relevant to the state of knowledge. The 2011 review, on the other hand, included consulting reports such as environmental and social assessments, as well as management plans and reports. These two reviews are thus not strictly comparable. However, based on the bibliography generated for this review, it is evident that while social science research outputs in the coastal and marine field over the period 1994-2012 have been variable, there has been an overall increase in published papers and book chapters and a substantial increase in student dissertations (Figure 1). Further, the African Journal of Marine Science (previously the South African Journal of Marine Science) has published an increasing number of articles since 1994 that could be broadly categorised as 'social science' (SC Pillar, DAFF, South Africa, pers. comm.). However, by comparison to the number of marine natural science articles, the contribution of social science remains very low.

\section{Limited funding within the marine funding pool allocated to social science research}

Funding for social science research in the marine environment has been provided from a range of sources both nationally and internationally. This is largely because of the broad ambit of research conducted across a range of sectors (tourism, recreation planning, fisheries, coastal management) and disciplines (anthropology, economics, law, sociology, geography, planning and environmental management), which results in researchers not necessarily targeting funding for marine social science research. A very small percentage of the overall SEAChange budget has been allocated to social science research (less than 5\%) for the period 2007-2011. However, it needs to be noted that some of the projects allocated funding under the 'Ecosystems and Society' thrust should not have fallen under this category and were thus not included in these calculations.

The low number of social science projects funded under the SEAChange programme is surprising given that part of the rationale for the new programme was precisely to broaden the scope of research to include the social sciences, pursue interdisciplinary research across the natural and social sciences, and adopt a more integrated and ecosystems-orientated approach to management (SANCOR 2006). This shift in focus was largely in response to evaluations of the Sea and Coast 1 and $\mathrm{ll}$ programmes (Fréon et al. 2000, Barange et al. 2005), which highlighted the lack of social science research as a key weakness of the programmes. It is also surprising given that SANCOR made a concerted effort to advertise the call for proposals widely and hosted two workshops, one in 2007 and the other in 2009, 
to inform social scientists of the SEAChange funding opportunities and identify areas of research need.

In a review of marine science in South Africa over the period 2001-2006, biologist Gibbons (2009) suggests that the lack of social science involvement in marine science was because natural and social scientists do not 'understand' each other's paradigms and, furthermore, that natural scientists are generally 'unwilling' to work with social scientists which would require them to 'move beyond their comfort zones' (Gibbons 2009, Scott 2013). Other reasons highlighted during this current review process included: the low number of social science submissions to SEAChange, especially in the early years of the programme; the purported poor quality of some of the social science proposals; (3) members of the review panels not necessarily having the background to judge the merits of the social science proposals; (4) the self-funded nature of some of the research groups active in this arena meant that the NRF was not an attractive funding source as it traditionally has not provided funding towards salaries; and finally, (5) many social scientists felt that their work was not understood or valued by natural scientists and hence did not apply. Clearly, these issues need to be addressed and appropriate procedures put in place in order to attract more social scientists to the SEAChange programme or its successor.

\section{Knowledge gaps}

Based on this review a number of knowledge gaps have emerged. The gaps presented here do not present a systematic analysis of research gaps in the marine social sciences arena. Rather, they represent those identified as part of this review process.

In terms of the contribution that coastal tourism can make to poverty alleviation and local economic development, further research is required to clarify the impacts and outcomes of these initiatives, especially in terms of resource sustainability and how marginalised communities can benefit. While existing research highlights enabling factors for sustainable tourism in selected case studies, this research needs to be scaled up and consolidated in order to prepare national guidelines to inform sustainable coastal tourism development. Understanding the impacts and implications of mine decommissioning in coastal areas, as well as the extent to which mining companies have met their environmental and social responsibilities, requires further investigation. This is especially needed in areas where reliance on marine resources is likely to be the alternative livelihood in the absence of other economic activities. To date, research on the socio-economic aspects of the recreational fishery has focused on descriptive statistics of socio-economic characteristics of selected fisheries as well as some economic analyses, but with little or no social analysis. Very few social science studies have been undertaken to understand the social and cultural impacts associated with recreational fisheries. This calls for greater collaboration between those working in the fields of economics, social anthropology, sociology, geography, conservation planning, fisheries management, marine biology and coastal management. 


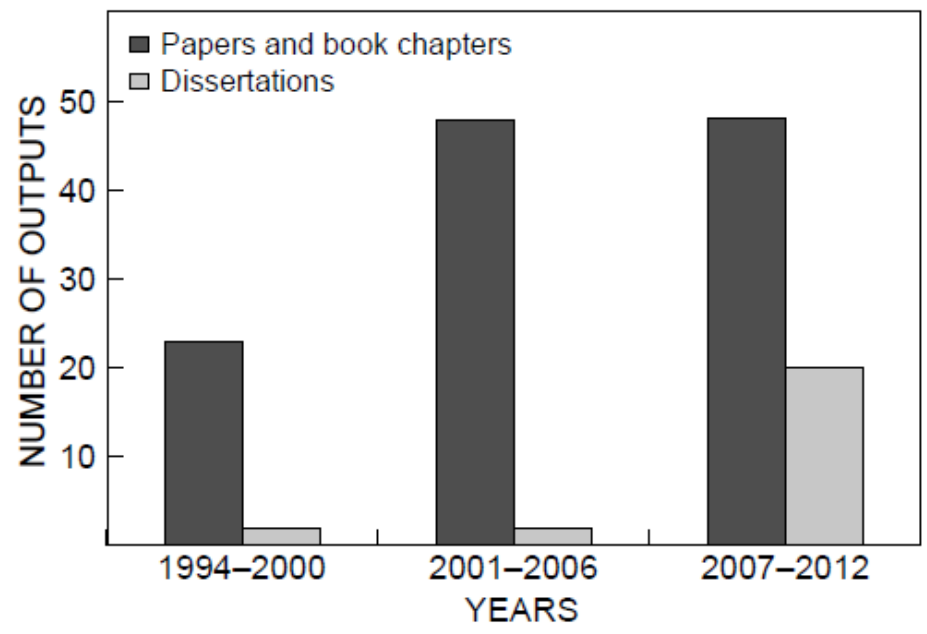

Figure 1: Status of marine social science outputs in South Africa (1994-2012)

Improved understanding of the human dimensions in all fishery sectors is urgently required if South Africa's commitments to adopt an EAF are to be achieved. Furthermore, the promulgation of the new small-scale fisheries policy (DAFF 2012b) will require reliable information on the socio-economic and cultural dimensions of coastal fishing communities. Studies conducted for the Benguela Current Large Marine Ecosystem [BCLME] programme (2003-2005), as well as recent studies under the auspices of the BCC and FAO, have highlighted that there are significant data and research gaps regarding the human dimensions of fisheries in South Africa and the region (Paterson et al. 2012). An essential requirement for operationalising information for fisheries management is the identification of appropriate indicators and the development of baseline datasets at the appropriate scale. Currently there is no central information management system that systematically gathers and analyses data on the human dimensions of the various fishery systems. Further, there are currently no agreed-upon indicators. This requires increasing social science capacity within the fisheries management authority. It also requires strengthening links between government and social scientists involved in socio-economic research in fisheries. While some progress has been made to develop an information management system for the small-scale fisheries sector in South Africa (Sowman et al. 2011a), this is limited to a few socio-economic variables and a narrow geographic range. Limited funding and capacity within DAFF is hampering further progress with this initiative.

The key gaps identified above emerged from this review but do not highlight key knowledge gaps and research needs that have been highlighted in other fora such as the 'Social science research in the marine environment' workshops held in Port Elizabeth (2007) and Cape Town (2009), nor the research needs emerging from a series of workshops facilitated by consultants to the previous fisheries authority, Marine and Coastal Management (MCM), to develop a 'Strategy for Fisheries Socio-economic Research' (Jayiya et al. 2008). A review of these various outputs could form the basis of discussions 
between social and natural scientists as well as coastal and marine managers regarding social science research priorities in the marine environment.

\section{Barriers to integration and uptake of social science research in management and decision-making}

There has been much rhetoric within the marine science community regarding the importance of social science research to improve understanding and management of coastal and marine systems. Whilst there has been progress since 1994 to include social scientists in the activities of the marine science community (conferences, workshops, seminars and funding calls), common concerns voiced by social scientists is that social science proposals have not been adequately funded by mainstream marine science funding sources, and that social science research is not understood and valued by the marine science community and consequently does not inform management decisions. These issues were raised at both workshops mentioned above and again highlighted by most contributing authors of this paper. Furthermore, the fact that only five social science projects were funded under the SEAChange programme between 2007-2011 reinforces this concern.

Whilst it is increasingly acknowledged that knowledge required for resource management is generated in various knowledge domains - natural science, social science, policy, management and traditional or local knowledge (Becker 2005, Roux et al. 2006, Garcia et al. 2008), the exchange and management of knowledge between these domains is necessary in order to enhance understanding of these complex systems and to identify creative and appropriate management solutions. However, there are a number of factors that mitigate against knowledge integration and limit the uptake of social science research to inform policy and management. The first relates to the different disciplinary perspectives of social and natural scientists, underpinned by different values, epistemologies and methodological approaches, which leads to differences in the way that knowledge is gathered, constructed and validated. Secondly, the worldview of the individual, which is influenced by education, past experiences and practical experience linked to specific social roles (Roux et al. 2006), shapes one's receptivity to new knowledge and ways of understanding the world. Thirdly, a high level of specialisation in a particular field may lead to 'trained incapacity' (Miller and Morris 1999) or 'tunnel vision' (Degnbol et al. 2006) which reduces the ability to embrace new knowledge and the realities that may emerge from a different knowledge field (Roux et al. 2006). Fourthly, in most resource management fields, including marine science, natural science has been the dominant paradigm (Degnbol et al. 2006, FAO 2009, Hushlak 2012). The hierarchy of knowledges and the power dynamics that exist between knowledge producers thus determines which knowledge counts and is valorised.

Knowledge integration requires researchers 'to be aware of their own and other's philosophical and epistemological positions' (Evely et al. 2008, p 52). It requires humility and recognition that knowledge is deeply contextual. It also requires respect of knowledge derived from other disciplines, worldviews and life experiences and a 
willingness to step outside one's knowledge 'comfort zone'. Finally, it requires collaboration across disciplines and sectors and promotion of truly interdisciplinary and transdisciplinary research, which begins with a collective framing of the problem or research question, collaborative sharing of knowledge and learning, through to the co-production of knowledge.

\section{Conclusion}

This review has revealed that a wide range of social science research in the marine environment has been undertaken since 1994. Research has been largely driven by socio-political events, knowledge gaps or the desire to apply new ideas, approaches and methods emerging in the international arena to the South African context. There is presently no clear research strategy guiding social science research in the marine environment. While research outputs reviewed could be categorised into nine themes, within the 'Coastal development and tourism' theme it was difficult to discuss 'the state of knowledge' in any meaningful way. However, in the other themes, there is a growing understanding of the key issues and debates and research has potential to inform management and policy. While there has been a general increase in social science marine research since 1994 (Figure 1), communication and dissemination of research findings to the marine science community has been limited. However, despite the limited uptake of marine social science, marine scientists are increasingly recognising the importance of taking a more holistic and integrated approach to management and realise that limited understanding of the socio-economic, cultural and governance dimensions of marine and fishery systems constrains achievement of long-term sustainability objectives.

The SEAChange programme has explicitly sought to support projects that enhance understanding of society and ecosystem interactions. Whilst this has been achieved to some extent, the relatively small number of social science projects funded under this programme suggests that social science research is still on the periphery of marine science in South Africa. Clearly, these issues need to be addressed and appropriate procedures put in place in order to attract more social scientists into the marine research environment. Development of a marine social science research strategy that is supported by the broad marine science community would assist in identifying key knowledge gaps, promote interdisciplinary research and enhance coordination amongst social and natural scientists. However, much more effort needs to be directed towards promoting truly interdisciplinary and transdisciplinary work in the marine environment. Such projects require researchers from different disciplines to work collaboratively on issues and problems and identify relevant research questions, agree on theoretical frameworks guiding the research as well as appropriate methodologies to undertake the work. Such collaborative knowledge integration requires respect for different knowledges and a willingness to jointly seek creative solutions to complex marine resource management problems. 


\section{References}

Agardy T. 1994. Advances in marine conservation: the role of marine protected areas. Trends in Ecology and Evolution 9: 267-270.

Ahmed F. 2008. Development pressures and management constraints in the coastal zone-the case of KwaZulu-Natal north coast. Alternations 15: 45-66.

Ahmed F. 2010. Approaches to and tools for managing environ- mental conflicts in coastal zones in Africa: challenges and prospects. African Journal of Conflict Resolution 10: $31-48$.

Anderson T. 2011. Tracking the movement of fish: skippers' logbooks and marine knowledge in fisheries management. MSocSc thesis, University of Cape Town, South Africa.

Ballance A, Ryan PG, Turpie JK. 2000. How much is a clean beach worth? The impact of litter on beach users in the Cape Peninsula, South Africa. South African Journal of Science 96: 210-213.

Barange M, Beckley L, Ekau W, Isaacs M. 2005. An evaluation of the Sea and Coast Programme. Paper presented at SAMSS (South African Marine Science Symposium), 8 July 2005, Durban, South Africa. Available at http://sancor.nrf.ac.za/SiteAssets/Programmes/Sea\%20and\%2oCoastII_Evaluatio n2. pdf [accessed September 2013].

Barbier E. 2012. Progress and challenges in valuing coastal and marine ecosystem services. Review of Environmental Economics and Policy 6: 1-19.

Bavinck M, Sowman M, Menin A. In press. Theorizing participatory governance in contexts of legal pluralism - a conceptual reconnaissance of fishing conflicts and their resolution. In: Bavinck

M, Pellegrini L, Mostert E (eds), Conflict and cooperation over natural resources conceptual approaches. New York: CRC Press. Beaumont J. 1997. Community participation in the establishment and management of Marine Protected Areas: a review of selected international experience. South African Journal of Marine Science 18: $333-340$.

Becker, K. 2005. Individual and organisational unlearning: directions for future research. International Journal of Organisational Behaviour 9: 659-670.

Beckley LE, Fennessy ST, Everett BI. 2008. Few fish but many fishers: a case study of shore-based recreational angling in a major South African estuarine port. African Journal of Marine Science 30: 11-24.

Berkes F, Colding J, Folke C (eds). 2003. Navigating social- ecological systems: building resilience for complexity and change. Cambridge: Cambridge University Press.

Berkes F, Mahon R, McConney P, Pollnac RC, Pomeroy RS. 2001. Managing small-scale fisheries: alternative directions and methods. Ottawa: International Development Research Centre. Available at: http://www.idrc.ca/booktique/ [accessed May 2003].

Blair I. 2011. In the wake of diamond mining: a critical assessment of environmental governance and corporate social responsibility in the Namaqualand coastal region. MPhil thesis, University of Cape Town, South Africa. 
Blair I, Scott K. 2011. Access to the coast in the Northern Cape. Unpublished report for South Africa-Nederlands Research Programme on Alternatives in Development [SANPAD] and the National Research Foundation [NRF]. Cape Town: Environmental Evaluation Unit, University of Cape Town.

Bohlin A. 2007. In the eyes of the sea: memories of place and displacement in a South African fishing town. Göteborg: Acta Universitatis Gothoburgensis.

Branch GM, Clark BM. 2006. Fish stocks and their management: the changing face of fisheries in South Africa. Marine Policy 30: 84-95.

Branch GM, Hauck M, Siqwana-Ndulo N, Dye AH. 2002a. Defining fishers in the South African context: subsistence, artisanal and small-scale commercial sectors. South African Journal of Marine Science 24: 475-487.

Branch GM, May J, Roberts B, Russell E, Clark BM. 2002b. Case studies on the socioeconomic characteristics and lifestyles of subsistence and informal fishers in South Africa. South African Journal of Marine Science 24: 439-462.

Brick K, Visser M, Burns J. 2012. Risk aversion: experimental evidence from South African fishing communities. American Journal of Agricultural Economics 94: 133-152.

Brouwer SL, Mann BQ, Lamberth SJ, Sauer WHH, Erasmus C. 1997. A survey of the South African shore-angling fishery. South African Journal of Marine Science 18: $165-177$.

Cardoso P, Fielding P, Sowman M. 2005. Overview and analysis of social, economic and fisheries information to promote artisanal fisheries management in the BCLME Region - South Africa: Final report and recommendations. Report for Benguela Current Large Marine Ecosystem (BCLME) Activity Centre for Marine Living Resources, Swakopmund, Namibia.

Celliers L, Moffett T, James NC, Mann BQ. 2004. A strategic assessment of recreational use areas for off-road vehicles in the coastal zone of KwaZulu-Natal, South Africa. Ocean \& Coastal Management 47: 123-140.

Charles A. 2001. Sustainable fishery systems. Oxford: Blackwell Science.

Chellan N, Khan S. 2008. Contesting ecotourism development in the iSimangaliso Wetland Park. Alternation 15: 268-289.

Christie P, McCay BJ, Miller ML, Lowe C, White AT, Stoffle R, Fluharty DL, McManus LT, Chuenpagdee R, Pomeroy C, Suman DO, Blount BG, Huppert D, Eisma RLV, Oracion E, Lowry K, Pollnac RB. 2003. Towards developing a complete understanding: social science research agenda for marine protected areas. Fisheries 28: 22-26.

Cincin-Sain B, Knecht RW. 1998. Integrated coastal and ocean management, concepts and practices. Washington, DC: Island Press.

Clark BM. 2004. Strategic environmental assessment to guide the implementation of regulations promulgated under the National Environmental Management Act 1998: control of vehicles in the coastal zone. Report to Marine and Coastal Management, Department of Environmental Affairs and Tourism. 
Clark BM, Hauck M, Harris JM, Salo K, Russell E. 2002. Identification of subsistence fishers, fishing areas, resource use and activities along the South African coast. South African Journal of Marine Science 24: 425-437.

Cochrane KL. 2000. Reconciling sustainability, economic efficiency and equity in fisheries: the one that got away? Fish and Fisheries 1: 3-21.

Cockcroft AC, Mackenzie AJ. 1997. The recreational fishery for West Coast rock lobster Jasus lalandii in South Africa. South African Journal of Marine Science 18: 75-84.

Colenbrander D. 2009. Exploring coastal spaces: towards linking social and ecological systems. MSocSc thesis, University of KwaZulu-Natal, South Africa.

Cooper J, Jayiya T, van Niekerk L, de Wit M, Leaner J, Moshe D. 2003. An assessment of the economic values of different uses of estuaries in South Africa. CSIR Report No. ENVS-C 2003-139. Stellenbosch: CSIR Environmentek.

Cousins B, Kepe T. 2004. Decentralisation when land and resource rights are deeply contested: a case study of the Mkambati eco-tourism project on the Wild Coast of South Africa. The European Journal of Development Research 16: 41-54.

Crosoer D, van Sittert L, Ponte S. 2006. The integration of South African fisheries into the global economy: past, present and future. Marine Policy 30: 18-29.

Crowe JP. 2012. A profile of the recreational fishery in Struisbaai. Implications for marine spatial planning. MPhil thesis, University of Cape Town, South Africa.

DAFF (Department of Agriculture, Forestry and Fisheries). 2012a. 2009/10 Performance review of fishing right holders. Pretoria: DAFF. DAFF (Department of Agriculture, Forestry and Fisheries). 2012b. Small-scale fisheries policy. Pretoria: DAFF.

Daniels R. 2001. The impact of income transfers on poverty levels in the subsistence fisheries sector. Trade and Industry Monitor 18: 2-5.

Daniels RC. 2002. Poverty alleviation in the subsistence fisheries sector. The South African Journal of Economics 70: 809-829. DEAT (Department of Environmental Affairs and Tourism). 1997. A marine fisheries policy for South Africa, White Paper. Pretoria: DEAT.

DEAT (Department of Environmental Affairs and Tourism). 2000. White Paper for sustainable coastal development in South Africa. Cape Town: Marine and Coastal Management, DEAT.

DEAT (Department of Environmental Affairs and Tourism). 2001. Medium term rights allocation. Pretoria: DEAT. Available at www. mcmdeat.gov.za/commercial/index.html [accessed 6 November 2008].

DEAT (Department of Environmental Affairs and Tourism). 2004. Transformation and the South African fishing industry: the TAC-controlled fisheries. Pretoria: DEAT.

DEAT (Department of Environmental Affairs and Tourism). 2005. General policy on the allocation and management of long term commercial rights: 2005. Pretoria: DEAT.

Degnbol P, Gislason H, Hanna S, Jentoft S, Raakjær Nielsen J, Sverdrup-Jensen S, Clyde Wilson D. 2006. Painting the floor with a hammer: technical fixes in fisheries management. Marine Policy 30: 534-543.

Dennis TL. 2010. Perceptions of history and policy in the Cape Agulhas area: could history influence policy on small-scale fishing? MPhil thesis, University of the Western Cape, South Africa. 
De Ruyck AMC, Soares AG, McLachlan A. 1995. Factors influencing human beach choice on three South African beaches: a multi- variate analysis. Geojournal 36: 345-352.

De Ruyck AMC, Soares AG, McLachlan A. 1998. Human recreational patterns on beaches with different levels of develop- ment. Transactions of the Royal Society of South Africa 52: 257-276.

De Young C, Charles A, Hjort A. 2008. Human dimensions of the ecosystem approach to fisheries: an overview of context, concepts, tools and methods. FAO Fisheries Technical Paper 489. Rome: Food and Agriculture Organization.

Dicken ML. 2010. Socio-economic aspects of boat-based ecotourism during the sardine run within the Pondoland Marine Protected Area, South Africa. African Journal of Marine Science 32: 405-411.

Dicken ML, Smale MJ, Booth AJ. 2006. Shark fishing effort and catch of the ragged-tooth shark Carcharias taurus in the South African competitive shore-angling fishery. African Journal of Marine Science 28: 589-601.

Dodson B, Kilian D. 1998. From port to playground: the redevelopment of the Victoria and Alfred Waterfront, Cape Town. In: Tyler D, Guerrier Y, Robertson M (eds), Managing tourism in cities. London: Wiley. pp 139-162.

Dray A. 2009. The politics of the privatisation of public space: the subsistence fishers of Durban. MSocSc thesis, University of KwaZulu-Natal, South Africa.

Duggan G. 2012. In the realm of the kob kings: fishers and fisheries management in Stilbaai. MSocSc thesis, University of Cape Town, South Africa.

Durrheim K, Dixon J. 2001. The role of place and metaphor in racial exclusion: South Africa's beaches as sites of shifting racialization. Ethnic and Racial Studies 24: 433-450.

Evely AC, Fazey I, Pinard M, Lambin X. 2008. The influence of philosophical perspectives in integrative research: a conservation case study in the Cairngorms National Park. Ecology and Society 13(2): 52. Available at http://www.ecologyandsociety.org/vol13/ iss2/art52/.

FAO (Food and Agriculture Organization). 2003. The ecosystem approach to fisheries. FAO Technical Guidelines for responsible fisheries No. 4, Suppl. 2. Rome: FAO.

FAO (Food and Agriculture Organization). 2009. Fisheries management. 2. The ecosystem approach to fisheries. 2.2 The human dimensions of the ecosystem approach to fisheries. FAO Technical Guidelines for Responsible Fisheries No. 4 Suppl. 2 Add. 2. Rome: FAO.

FAO (Food and Agriculture Organization). 2011. Fisheries management. 4. Marine protected areas and fisheries. FAO Technical Guidelines for Responsible Fisheries No. 4, Suppl. 4. Rome: FAO.

Fassen H, Watts S. 2007. Local community reaction to the 'no-take' policy on fishing in the Tsitsikamma National Park, South Africa. Ecological Economics 64: 36-46.

Ferreira S, Visser G. 2007. Creating an African Riviera: revisiting the impact of the Victoria and Alfred Waterfront Development in Cape Town. Urban Forum 18: 227-246.

Fielding P. 2011. Access to the coast in the Eastern Cape. Unpublished report for South Africa-Nederlands Research Programme on Alternatives in Development] 
[SANPAD] and the National Research Foundation [NRF]. Cape Town: Environmental Evaluation Unit, University of Cape Town.

Findlay KP. 1997. Attitudes and expenditures of whale watchers in Hermanus, South Africa. South African Journal of Wildlife Research 27: 57-62.

Fréon P, van der Westhuizen OA, Mather D. 2000. An evaluation of the Sea and the Coast Programme l. Cape Town: SANCOR [South African Network for Coastal and Oceanic Research]. Garcia SM, Allison EH, Andrew NJ, Béné C, Bianchi G, de Graaf

GJ, Kalikoski D, Mahon R, Orensanz JM. 2008. Towards integrated assessment and advice in small-scale fisheries: principles and processes. FAO Fisheries Technical Paper No. 515. Rome: Food and Agriculture Organization.

Gezelius SS. 2003. Regulations and compliance in the Atlantic fisheries: state/society relations in the management of natural resources. Dordrecht: Kluwer Academic publishers.

Gezelius SS, Hauck M. 2011. Toward a theory of compliance in self-regulated livelihoods: a comparative study of compliance motivations in developed and developing world fisheries. Law and Society Review 45: 435-470.

Gibbons MJ. 2009. A biologist's personal overview of the marine science community and its outputs (2001-2006). Unsolicited Report to SANCOR (South African Network for Coastal and Oceanic Research).

Gibbons M[J], Limoge C, Nowotny H, Schwartzman S, Scott C, Trown M. 1994. The new production of knowledge: the dynamics of science and research in contemporary societies. London: Sage. Glavovic BC. 2000. A new coastal policy for South Africa. Coastal Management 28: 261-271.

Glavovic BC. 2006a. Coastal sustainability an - elusive pursuit?: Reflections on South Africa's coastal policy experience. Coastal Management 34: 111-132.

Glavovic BC. 2006b. The evolution of coastal management in South Africa: Why blood is thicker than water. Ocean \& Coastal Management 49: 889-904.

Glavovic BC, Boonzaier S. 2007. Confronting coastal poverty: Building sustainable coastal livelihoods in South Africa. Ocean \& Coastal Management 50: 1-23.

Glavovic BC, Cullinan C. 2009. The coast. In: Strydom HA, King ND (eds), Environmental management in South Africa. Johannesburg: Juta \& Co. pp 868920.

Goudie S, Kilian D, Dodson B. 1995. Postmodern f(r)ictions: history, text and identity at the Victoria and Alfred Waterfront. Architecture SA May/June: 26-31.

Govender Y, Jury MR, Mthembu A, Hatesse S, Bulfoni E. 2005. Socio-economic status and development potential of a rural community on the Maputaland coast of South Africa. South African Geographical Journal 87: 37-42.

Grant L, Scott D. 1996. Waterfront developments as tools for urban reconstruction and regeneration in South Africa: the planned point waterfront development in Durban. Urban Forum 7: 125-138.

Green LJF. 2012. Beyond South Africa's 'indigenous knowledge - science' wars. South African Journal of Science 108(7/8): Art. \#631, 10 pages. Doi 10.4102/sajs.v108i7/8.631. 
Griffiths MH, Lamberth SJ. 2002. Evaluating the marine recreational fishery in South Africa. In: Pitcher TJ, Hollingworth CE (eds), Recreational fisheries: ecological, economic and social evaluation. Oxford: Blackwell. pp 227-251.

Hajer M. 1995. The politics of environmental discourse: ecological modernization and the policy process. Oxford: Clarendon Press.

Hajer M, Wagenaar H. 2003. Introduction. In: Hajer M, Wagenaar H (eds), Deliberative policy analysis: understanding governance in the network society. Cambridge: Cambridge University Press. pp 5-38.

Hara M, Raakjær J. 2009 Policy evolution in South African fisheries: the governance of the sector for small pelagics. Development Southern Africa 26: 649-662.

Harris J, Branch G, Clark B, Cockcroft A, Coetzee C, Dye A, Hauck M, Johnson A, Kati-Kati L, Maseko Z, Salo K, Sauer WHH, Siqwana-Ndulo N, Sowman M. 2002b. Recommendations for the management of subsistence fisheries in South Africa. South African Journal of Marine Science 24: 503-523.

Harris JM, Branch GM, Clark BM, Sibiya C. 2007. Redressing access inequities and implementing formal management systems for marine and estuarine subsistence fisheries in South Africa. In: McClanahan TR, Castilla JC (eds), The process of developing a management system for subsistence fisheries in South Africa: recognizing and formalizing a marginalized fishing sector in South Africa. Oxford: Blackwell Publishing. pp 112-128.

Harris J[M], Branch G[M], Sibiya C, Bill C. 2003. The Sokhulu subsistence musselharvesting project: co-management in action. In: Sowman M, Hauck M (eds), Waves of change: coastal and fisheries co-management in South Africa. Cape Town: University of Cape Town Press. pp 61-98.

Harris J[M], Sowman M, Branch G, Clark B, Cockcroft A, Coetzee C, Dye A, Hauck M, Johnston A, Kati-Kati L. 2002a. The process of developing a management system for subsistence fishers: recognizing and formalizing a marginalized fishing sector in post-apartheid South Africa. South African Journal of Marine Science 24: $405-424$.

Harriss J. 2002. The case for cross-disciplinary approaches in international development. World Development 30: 487-496.

Hatcher A, Jaffry S, Thebaud O, Bennett E. 2000. Normative and social influences affecting compliance with fishery regulations. Land Economics 76: 448-462.

Hauck M. 1999a. Seawatch: civil society's role in combating environmental crime. South African Journal of Environmental Law and Policy 6:101-119.

Hauck M. 1999b. Regulating marine resources in South Africa: the case of the abalone fishery. In: Glazewski J, Bradfield G (eds), Environmental justice and the legal process. Cape Town: Juta. pp 211-228.

Hauck M. 2007. Non-compliance in small-scale fisheries: a threat to security? In: Beirne $\mathrm{P}$, South $\mathrm{N}$ (eds), Issues in green criminology: confronting harms against environments, humanity and other animals. London: Willan Publishing. pp 270289.

Hauck M. 2008. Rethinking small-scale fisheries compliance. Marine Policy 32: 635642. 
Hauck M. 2009a. Rethinking small-scale fisheries compliance: from criminal justice to social justice. PhD thesis, University of Cape Town, South Africa.

Hauck M. 2009b. Crime, environment and power: revisiting the abalone fishery. South African Journal of Criminal Justice 22: 229-245.

Hauck M. 2011. Small-scale fisheries compliance: integrating social justice, legitimacy and deterrence. In: Pomeroy RS, Andrew NL (eds), Small-scale fisheries management: frameworks and approaches for the developing world. Wallingford: Cabi Publishers. pp 196-215.

Hauck M, Hector R. 2003. Towards abalone and rock lobster co-management in the Hangklip-Kleinmond area. In: Hauck M, Sowman M (eds), Waves of change: coastal and fisheries co-management in South Africa. Cape Town: University of Cape Town Press. pp 247-268.

Hauck M, Kroese M. 2006. Fisheries compliance in South Africa: a decade of challenges and reform 1994-2004. Marine Policy 30: 74-83.

Hauck M, Sowman M. 2001. Coastal and fisheries co-management in South Africa: an overview and analysis. Marine Policy 25: 173-185. Hauck M, Sowman M. 2003a. Comanagement of coastal and fisheries resources in South Africa: policy and legislative framework. In: Hauck M, Sowman M (eds), Waves of change: coastal and fisheries co-management in South Africa. Cape Town: University of Cape Town Press. pp 247-268.

Hauck M, Sowman M (eds). 2003b. Waves of change: coastal and fisheries comanagement in South Africa. Cape Town: University of Cape Town Press.

Hauck M, Sowman M, Clark B, Russell BE, Harris J, Venter MA, Beaumont J, Maseko Z. 2002. Perceptions of subsistence and informal fishers in South Africa regarding the management of living marine resources. South African Journal of Marine Science 24: 463-474.

Hauck M, Sweijd NA. 1999. A case study of abalone poaching in South Africa and its impact on fisheries management. ICES Journal of Marine Science 56: 1024-1032.

Heal GM, Barbier EB, Boyle KJ, Covich AP, Goss SP, Herschner CH, Hoehn JP, Pringle CM, Polasky S, Segerson K, Shrader-Frechette K. 2005. Valuing ecosystem services: toward better environmental decision making. Washington, DC: National Academies Press.

Hemson C. 2001. Ukubekezela or ukuzithemba: African lifesavers in Durban. In: Morrell R (ed.), Changing men in southern Africa. Pietermaritzburg: University of Natal Press. pp 57-74.

Hersoug B. 2002. Transforming South Africa's fishing industry. In: Hersoug B (ed.), Fishing in a sea of sharks: reconstruction and development in the South African fishing industry. Delft: Eburon. pp 11-45.

Hersoug B, Holm P. 2000. Change without redistribution: an institutional perspective on South Africa's new fisheries policy. Marine Policy 24: 221-231.

Hosking SG, du Preez M, Campbell EE, Woolridge TH, du Plessis LL. 2002. Evaluating the environmental use of water - selected case studies in the Eastern and Southern Cape. WRC Report no. 1045/1/02. Pretoria: Water Research Commission. 
Hushlak A. 2012. Fishing for knowledge: integrating traditional ecological knowledge in South Africa's small-scale fisheries: the Olifants Estuary. MPhil thesis, University of Cape Town, South Africa.

Hutchings K, Lamberth SJ, Turpie JK. 2002. Socio-economic characteristics of gillnet and beach-seine fishers in the Western Cape, South Africa. South African Journal of Marine Science 24: 243-262.

Hutton T, Pitcher TJ. 1998. Current directions in fisheries management policy: a perspective on co-management and its application to South African fisheries. South African Journal of Marine Science 19: 471-486.

Isaacs M. 2001. Subsistence fishing in South Africa: social policy of commercial microenterprise? Commons Southern Africa 3: 20-22.

Isaacs M. 2003. Understanding the social processes and the politics of implementing a new fisheries policy, the Marine Living Resource Act 18 of 1998, in South Africa. PhD thesis, University of the Western Cape, South Africa.

Isaacs M. 2006. Small-scale fisheries reform. Expectations, hopes and dreams of 'a better life for all'. Marine Policy 30: 51-59.

Isaacs M. 2011. Creating action space: small-scale fisheries policy reform in South Africa. In: Jentoft S, Eide A (eds), Poverty mosaics: realities and prospects in small-scale fisheries. Dordrecht: Springer. pp 359-382.

Isaacs M. 2012. Individual transferable quotas, poverty alleviation and challenges for small-country fisheries policy in South Africa. Maritime Studies 10: 63-84.

Isaacs M, Hara M. 2008. Mainstreaming of HIV and AIDS into South African fisheries policy. PLAAS Research Report No. 39. Cape Town: Programme for Land and Agrarian Studies, University of the Western Cape.

Isaacs M, Hara M, Raakjaer J. 2007. Has reforming South African fisheries contributed to wealth redistribution and poverty alleviation? Ocean and Costal Management 50: 301-313.

Jaumain S. 2009. A study of changing coastal access patterns: Richards Bay. MPhil thesis, University of Cape Town, South Africa.

Jayiya T, Hara M, de Wit M, Crookes D. 2008. Strategy for fisheries socio-economic research. PLAAS Working Paper No. 5. Cape Town: Institute for Poverty, Land and Agrarian Studies.

Jones T. 2002. The port of Durban. In: Freund B, Padayachee V (eds), (D)urban vortex: South African city in transition. Pietermaritzburg: University of Natal Press. pp 69106.

Kapelus P. 2002. Mining, corporate social responsibility and the 'community': The case of Rio Tinto, Richards Bay Minerals and the Mbonambi. Journal of Business Ethics 39: 275-296.

Kemp LV, Branch GM, Attwood CA, Lamberth SJ. 2009. The 'fishery' in South Africa's remaining coastal stonewall fish traps. African Journal of Marine Science 31: 55-62.

Kepe T. 2001. Tourism, protected areas and development in South Africa: views of visitors to Mkambati Nature Reserve. South African Journal of Wildlife Research 31: 155159. 
Kilian D. 1994. Change, conflict and sense of place: a case study of the inshore fishing community in the Victoria and Alfred Waterfront. MSocSc thesis, University of Cape Town, South Africa.

Kilian D, Dodson B. 1995. The capital see-saw: understanding the rationale for the Victoria and Alfred redevelopment. South African Geographical Journal 77: 12-20.

Kilian D, Dodson B. 1996a. Between the devil and the deep-blue sea: functional conflicts in Cape Town's Victoria and Alfred Waterfront. Geoforum 27: 495-507.

Kilian D, Dodson B. 1996b. Forging a postmodern waterfront: urban form and spectacle at docklands. South African Geographical Journal 78: 29-40.

Kirkby K. 2011. Role of the environmental impact assessment process in safeguarding access to the coast. MSc thesis, University of Cape Town, South Africa.

Kleinschmidt H, Sauer WHH, Britz PJ. 2003. Commercial fishing rights allocation in postapartheid South Africa: reconciling equity and stability. African Journal of Marine Science 25: 25-35.

Koch E, de Beer G, Elliffe S and others. 1998. SDIs, tourism-led growth and the empowerment of local communities in South Africa. Development Southern Africa 15: 809-826.

Kooiman J, Banvick M, Jentoft S, Pullin R (eds). 2005. Fish for life: interactive governance for fisheries. Amsterdam: Amsterdam University Press.

Krige S, Morrell P 2007. An historical review and analysis of the NRF rating system 19832005. Pretoria: National Research Foundation. Kruger F, van Wilgen BW, Weaver AV, Greyling T. 1997. Sustainable development and the environment: lessons from the St Lucia environmental impact assessment. South African Journal of Science 93: 23-33.

Kyle R. 2003. Kosi Bay gillnetting: a community-based joint management fishery inside a nature reserve. In: Sowman M, Hauck M (eds), Waves of change: coastal and fisheries co-management in South Africa. Cape Town: University of Cape Town Press. pp $123-145$.

Lamberth SJ, Turpie JK. 2003. The role of estuaries in South African fisheries: economic importance and management implications. African Journal of Marine Science 25: 131-157.

Lee DE. 2012. An application of the choice experiment method to estimate wilingess to pay for and guide management on estuarine recreation services. PhD thesis, Nelson Mandela Metropolitan University, South Africa.

Leibold M, van Zyl CJ. 2007. The economic impact of sport and recreational angling in the Republic of South Africa 2007: report of project to scientifically determine the overall economic impact and strategic value of sport and recreational angling in the Republic of South Africa. Commissioned by SADSAA [South African Deep Sea Angling Association].

Lutjeharms JLR, Shannon LV. 1997. A century of physical oceanography in South Africa: in search of the legacy of John DF Gilchrist. Transactions of the Royal Society of South Africa 52: 17-50.

Luyeye N. 2011 Integrating the human dimension of an ecosystem approach to fisheries (EAF) into fisheries management in the BCC region. Baseline Report: Angola. 
Unpublished report for the Benguela Current Commission [BCC] and Food and Agriculture Organization [FAO]. Namibia Nature Foundation.

Mann BQ, James NC, Beckley LE. 2002. An assessment of the recreational fishery in the St Lucia estuarine system,

KwaZulu-Natal, South Africa. South African Journal of Marine Science 24: 263-279.

Mann BQ, McDonald AM, Sauer WHH, Hecht T. 2003. Evaluation of participation in and management of the Transkei shore linefishery. South African Journal of Marine Science 25: 79-97.

Mann BQ, Pradervand P, Maggs JQ, Wintner S. 2012. A characterisation of the paddleski fishery in KwaZulu-Natal, South Africa. African Journal of Marine Science 34: 119-130.

Mascia M, Claus C, Naidoo R. 2010. Impacts of marine protected areas on fishing communities. Conservation Biology 24: 1424-1429.

Mather D, Britz PJ, Hecht T, Sauer WHH (eds). 2003. An economic and sectoral study of the South African fishing industry. Vol. 1: economic and regulatory principles, survey results, transformation and socio-economic impact and Vol. 2: fishery profiles. Report for prepared for Marine and Coastal Management, Department of Environmental Affairs and Tourism. Grahamstown: Rhodes University.

Max-Neef MA. 2005. Foundations of transdisciplinarity. Ecological Economics 53: 5-16.

Mbatha NP. 2011. Sharing benefits from coastal resources with rural communities in South Africa: the influence of institutional arrangements. MSocSc thesis, University of Cape Town, South Africa.

McCarthy J, Baxter G, Schroenn J, McGrath M, Forbes A, Parnell S. 1998. Coastal economy specialist study. Unpublished report for the White Paper for Sustainable Coastal Development for the Department of Environmental Affairs and Tourism on behalf of Common Ground Consulting.

McGrath MD, Horner CCM, Brouwer SL, Lamberth SJ, Mann BQ, Sauer WHH, Erasmus C. 1997. An economic valuation of the South African linefishery. South African Journal of Marine Science 18: 203-211.

MDT (Masifundise Development Trust). 2010. A handbook towards sustainable small-scale fisheries in South Africa. Cape Town: MDT.

Miller WL, Morris L. 1999. 4th generation R\&D - managing knowledge, technology, and innovation. New York: John Wiley. Mitchell S, Andersson N, Ngxowa N, Merhi S. 2008. A community-based impact assessment of the Wild Coast spatial development initiative 1997-2004. Development Southern Africa 25: 119-132.

Mograbi M, Rogerson CM. 2007. Maximising the local pro-poor impacts of dive tourism: Sodwana Bay, South Africa. Urban Forum 18: 85-104.

Morgan CE. 1996. Addressing the conflict of interests of humans and Jackass penguins at Boulders Beach, Cape Town. MSc thesis, University of Cape Town, South Africa.

Murray G, Neis B, Palmer CT, Schneider DC. 2008. Mapping cod: fisheries science, fish harvesters' ecological knowledge, and cod migrations in the Northern Gulf of St Lawrence. Human Ecology 36: 581-598. 
Mwandla ND. 1995. Blacks and the coast: current demands and future aspirations for coastal recreation in the KwaZulu-Natal North Coast. MA thesis, University of Zululand, South Africa.

Myeza PJ. 2007. The use of the sardine run as a marketing tool by indigenous business and its economic effect on the South Coast indigenous population. MTech thesis, Durban University of Technology, South Africa.

Myeza J, Mason RB, Peddemors VM. 2010. Socio-economic implications of the KwaZuluNatal sardine run for local indigenous communities. African Journal of Marine Science 32: 399-404.

Napier VR, Branch GM, Harris JM. 2005. Evaluating conditions for successful comanagement of subsistence fisheries in KwaZulu- Natal, South Africa. Environmental Conservation 32: 165-177.

Napier VR, Turpie JK, Clark BM. 2009. Value and management of the subsistence fishery at Knysna Estuary, South Africa. African Journal of Marine Science 31: 297-310.

Nel E, Binns T. 2002. Place marketing, tourism promotion, and community-based local economic development in post-apartheid South Africa: The case of Still Bay - The "Bay of Sleeping Beauty". Urban Affairs Review 38: 184-208.

Nel DC, Cochrane K, Petersen SL, Shannon LJ, van Zyl B, Honig MB. 2007. Ecological risk assessment: a tool for implementing an ecosystem approach for southern African fisheries. WWF South Africa Report Series - 2007/Marine/o02.

Nowotny HP, Scott P, Gibbons M. 2001. Re-thinking science, knowledge and the public in an age of uncertainty. Cambridge: Cambridge Polity Press.

Ntonzima L, Binza MS. 2011. Prioritisation of the tourism industry as a local economic development sector approach for rural coastal areas in South Africa: the case of the Transkei Wild Coast community. Journal of Public Administration 46: 654-668.

Omari N. 2007. Legal pluralism in environmental management: informal rules and noncompliance in the Karbonkelberg marine protected area. MPhil thesis, University of Cape Town, South Africa.

Ommer RE. 2007. Coasts under stress: restructuring and social- ecological health. Montreal, Canada: McGill-Queen's University Press.

Palmer BJ, Hill TR, Mcgregor GK, Paterson AW. 2011. An assessment of coastal development and land use change using the DPSIR framework: case studies from the Eastern Cape, South Africa. Coastal Management 39: 158-174.

Palmer BJ, McGregor GK, Hill TR, Paterson AW. 2010. A spatial assessment of coastal development and land use change in the Eastern Cape, South Africa. South African Geographical Journal 92: 117-128.

Paterson B, Isaacs M, Hara M, Jarre A, Moloney CL. 2010. Transdisciplinary co-operation for an ecosystem approach to fisheries: a case study from the South African sardine fishery. Marine Policy 34: 782-794.

Paterson B, Jarre A, Moloney CL, Fairweather TP, van der Lingen CD, Shannon LJ, Field JG. 2007. A fuzzy-logic tool for multi-criteria decision making in fisheries: the case of the South African pelagic fishery. Marine and Freshwater Research 58: 1056-1068.

Paterson B, Petersen SL. 2010. EAF implementation in southern Africa: lessons learnt. Marine Policy 34: 276-292. 
Paterson B, Sowman M, Russell D. 2012. Report on recommen- dations towards the collection and analysis of information on the human dimensions of fisheries in the Benguela Current Region with particular emphasis on EAF. Report EAF 09/12 for FAO-BCC Project.

Ponte S, van Sittert L. 2007. The chimera of redistribution in post-apartheid South Africa: 'Black Economic Empowerment' (BEE) in industrial fisheries. African Affairs 106: 437-462.

Preston-Whyte R. 2001. Constructed leisure space: the seaside at Durban. Annals of Tourism Research 28: 581-596.

Preston-Whyte R. 2002. Constructions of surfing space at Durban, South Africa. Tourism Geographies: an International Journal of Tourism Space, Place and Environment 4: 307-328.

Preston-Whyte R, Oelofse C. 2007. The development of South Africa's coastal tourism resorts. In: Agarwa lA, Shaw G (eds), Managing coastal tourism resorts, a global perspective. London: Multilingual Matters. pp 187-203.

Prochazka K, Kruger LM. 2001. Trends in beach utilisation on the Cape Peninsula, South Africa, during and after apartheid. Transactions of the Royal Society of South Africa 56: 25-40.

Raakjær Nielsen J. 2003. An analytical framework for studying: compliance and legitimacy in fisheries management. Marine Policy 27: 425-432.

Raakjær Nielsen J, Hara MM. 2006. Transformation of South African industrial fisheries. Marine Policy 30: 43-50.

Raemaekers S. 2009. Rethinking South Africa's small-scale fisheries management paradigm and governance approach: evidence from the Eastern Cape. PhD thesis, Rhodes University, South Africa.

Raemaekers S, Britz P. 2009. Profile of the illegal abalone fishery (Haliotis midae) in the Eastern Cape province, South Africa: organised pillage and management failure. Fisheries Research 97: 183-195.

Raemaekers S, Hauck M, Britz PJ, Bürgener M, Plaganyi E, Maharaj G, Mackenzie A. 2011. Review of the causes of the rise of the illegal South African abalone fishery and consequent closure of the rights-based fishery. Ocean \& Coastal Management 54: 433-445.

Ragaller S. 2012. Misunderstandings in fisheries: an ethnography of regulative categories and communication around Gansbaai and Dyer Island. MSocSc thesis, University of Cape Town, South Africa.

Ribot J, Peluso N. 2003. A theory of access. Rural Sociology 68: 153-181.

Rogerson J. 2011. Above the surface, beneath the waves: Contesting ecologies and generating knowledge conversations in Lamberts Bay. MSocSc thesis, University of Cape Town, South Africa.

Roux DJ, Rogers KH, Biggs HC, Ashton PJ, Sergeant A. 2006. Bridging the sciencemanagement divide: moving from unidirectional knowledge transfer to knowledge interfacing and sharing. Ecology and Society 11: 4. Available at http://hdl.handle. net/10204/953. 
RSA (Republic of South Africa). 1996. Growth, employment and redistribution: a macroeconomic strategy. Pretoria: RSA.

RSA (Republic of South Africa). 1998. Marine Living Resources Act 1998 (Act No. 18 of 1998). Government Gazette, South Africa 395 (18930).

RSA (Republic of South Africa). 2001. GN Regulation 1399. National Environment Management Act (107/1998): Regulations: control of vehicles in the coastal zone. Government Gazette, South Africa 438 (22960).

RSA (Republic of South Africa). 2003. South Africa's economic transformation: a strategy for broad-based black economic empowerment. Pretoria: Department of Trade and Industry.

RSA (Republic of South Africa). 2009. National Environmental Management: Integrated Coastal Management Act 2008 (Act No. 24 of 2008). Government Gazette, South Africa 524 (31884).

Russell E. 2011. Integrating the human dimension of an ecosystem approach to fisheries (EAF) into fisheries management in the BCC region. Baseline report: Namibia. Unpublished report for the Benguela Current Commission [BCC] and Food and Agriculture Organization [FAO]. Namibia Nature Foundation.

Saayman M, Van der Merwe P, Saayman A, Mouton ME. 2009. The socio-economic impact of an urban park: the case of Wilderness National Park. Journal of Policy Research in Tourism, Leisure and Events 1: 247-264.

Sale M. 2005. Application of the contingent valuation method to value the freshwater inflows into the Kowie and the Kromme estuaries. In: Turpie JK, Hosking S (eds), Proceedings of a national workshop on resource economics as a tool for the management and conservation of estuaries in South Africa; 10-11 March 2005, Velddrif, South Africa. Cape Town: Anchor Environmental Consultants. pp 136-146.

SANCOR. 2006. Society, Ecosystems and Change (SEAChange) Programme description. Available at http://sancor.nrf.ac.za/ programmes/seachange-programme/societyecosystems-and- change-seachange [accessed 5 August 2012].

Sauer WHH, Hecht T, Britz PJ, Mather D. 2003. An economic and sectoral study of the South African fishing industry. Vol. 1. Economic and regulatory principles, survey results, transformation and socio-economic impact. Report prepared for Marine and Coastal Management, Department of Environmental Affairs and Tourism. Grahamstown: Rhodes University.

Schell N. 2011. Small-scale fisheries in South Africa: Stakeholders' understandings and perceptions of co-management, South Africa. MPhil thesis, University of Cape Town, South Africa.

Scherman Colloty and Associates. 2011. State of marine and coastal research in South Africa: 1994-2008. Report for Rhodes University, SANCOR [South African Network for Coastal and Oceanic Research], National Research Foundation, and Department of Environmental Affairs. Grahamstown: Scherman Colloty and Associates.

Schnetler A. 1993. South African Network for Coastal and Oceanic Research. SANCOR Newsletter 136: 2-3. 
Schultz OJ. 2010. Belonging on the West Coast. An ethnography of St. Helena Bay in the context of marine resource scarcity, South Africa. MSocSc thesis, University of Cape Town, South Africa.

Scott D. 2013. Science, transformation and society: a contextual analysis of South Africa's SANCOR-managed marine and coastal research programmes. African Journal of Marine Science 35: 361-383.

Scott D, Oelofse C. 2007. The 'framing' of a social impact assessment: The Point small craft harbour, Durban. Environmental Management 2: 13-16.

Scott K. 2006. The environmental politics of the proposed small craft harbour, Durban: a discourse analysis approach. MSc thesis, University of KwaZulu-Natal, South Africa.

Scott K. 2011. Access to the coast in KwaZulu-Natal. Unpublished report for South AfricaNederlands Research Programme on Alternatives in Development [SANPAD] and the National Research Foundation [NRF]. Cape Town: Environmental Evaluation Unit, University of Cape Town.

Scott K, Sowman M. 2012. Access to the Coast in South Africa. Unpublished report for South Africa-Nederlands Research Programme on Alternatives in Development [SANPAD] and the National Research Foundation [NRF]. Cape Town: Environmental Evaluation Unit, University of Cape Town.

SFTG (Subsistence Fisheries Task Group). 2000. A socio-economic and resource management profile of subsistence fisheries in South Africa. SFTG Report 2 for Department of Environmental Affairs and Tourism: Marine and Coastal Management. Cape Town.

Shannon LJ, Cochrane KL, Pillar SC (eds). 2004. Ecosystem approaches to fisheries in the southern Benguela. African Journal of Marine Science 26: Special Issue.

Shanyengange M. 2009. Assessing the contribution of interim relief measures to food security and income of small-scale fishers in Ocean View, Western Cape. MPhil thesis, University of Cape Town, South Africa.

Sowman M. 2003. Co-management of the Olifants River harder fishery. In: Hauck M, Sowman M (eds), Waves of change: coastal and fisheries co-management in South Africa. Cape Town: University of Cape Town Press. pp 269-297.

Sowman M. 2006. Subsistence and small-scale fisheries in South Africa: a ten-year review. Marine Policy 30: 60-73.

Sowman M. 2011. New perspectives in small-scale fisheries management: challenges and prospects for implementation in South Africa. African Journal of Marine Science 33: $297-311$.

Sowman M, Beaumont J, Bergh M, Maharaj G and K Salo. 1997. An analysis of emerging comanagement arrangements for the Olifants River harder fishery, South Africa. In: Fisheries co-management in Africa; proceedings from a regional workshop on fisheries co-management research, 18-20 March 1997, Mangochi, Malawi. Fisheries Co-management Research Project Research Report No. 12. Denmark: Innovative Fisheries Management. pp 153-165.

Sowman M, Cardoso P. 2010. Small-scale fisheries and food security strategies in countries in the Benguela Current Large Marine Ecosystem (BCLME) region: Angola, Namibia and South Africa. Marine Policy 34: 1163-1170. 
Sowman M, Hauck M, Branch G. 2003. An analysis of coastal and fisheries co-management in South Africa: lessons learned from nine case studies. In: Sowman M, Hauck M (eds), Waves of change: coastal and fisheries co-management in South Africa. Cape Town: University of Cape Town Press. pp 299-340.

Sowman M, Hauck M, Sunde J, Raemaekers S. 2011c. Conceptual framework for identifying and addressing human dimensions of marine protected areas (MPAs). Unpublished report. Cape Town: Environmental Evaluation Unit, University of Cape Town.

Sowman M, Hauck M, van Sittert L, Sunde J. 2011b. Marine protected areas in South Africa: new policies, old paradigms. Environmental Management 47: 573-583.

Sowman M, Hauck M, Williams S, Neethling K, Authar R, Fielding P, Phillips T, Gquyatana A. 2008. Effective sustainable livelihood options for fishers in three coastal communities. Unpublished report for National Environmental Advisory Forum. Cape Town: Environmental Evaluation Unit, University of Cape Town.

Sowman M, Raemaekers S, Sunde J, Schell N, Schultz O. 2011a. Integrating the human dimension of an ecosystem approach to fisheries (EAF) into fisheries management in the BCC Region. Baseline Report: South Africa. Unpublished report for Benguela Current Commission [BCC] and Food and Agriculture Organization [FAO]. Cape Town: Environmental Evaluation Unit, University of Cape Town.

Sowman M, Rajagopalan R, Sharma C, Sunde J. In press. Making space for small-scale fishing communities: The use of spatial management measures in fisheries management and marine conservation. In: Garcia SM, Rice T, Charles AT (eds), Governance for fisheries and marine conservation: interactions and co-evolution. Chichester: Wiley-Blackwell.

Sowman M, Sunde J, Raemaekers S, Schultz O. 2012. Fishing for equality: policy for poverty alleviation for South Africa's small-scale fisheries. Unpublished Conference Proceedings, Conference on Strategies to Overcome Poverty and Inequality. Towards Carnegie III conference, 3-7 September 2012, University of Cape Town, South Africa.

Sunde J. 2011. Access to the coast in the Western Cape. Unpub- lished report for South Africa-Nederlands Research Programme on Alternatives in Development [SANPAD] and the National Research Foundation [NRF]. Cape Town: Environmental Evaluation Unit, University of Cape Town.

Sunde J, Isaacs M. 2008. Marine conservation and coastal communities... who carries the costs? A study of marine protected areas and their impact on traditional small-scale fisher communities in South Africa. Chennai: International Collective in Support of Fishworkers.

Sunde J, Sowman M, Smith H, Wicomb W. 2013. Emerging proposals for tenure governance in small-scale fisheries in South Africa. Land Tenure Journal 1-13: 117146.

Thompson G. 2011. Reimagining Surf City: surfing and the making of the post-apartheid beach in South Africa. The International Journal of the History of Sport 28: 21152129.

Tovey H. 2008. Introduction: rural sustainable development in the knowledge society era. Sociologica Ruralis 48: 185-199. 
Turpie JK, Clark BM. 2007. The health status, conservation importance, and economic value of temperate South African estuaries and development of a regional conservation plan. Report to CapeNature.

Turpie JK, Clark BM, Cowley P, Bornman T, Terörde A. 2009. Integrated ecologicaleconomic modelling as an estuarine management tool: a case study of the East Kleinemonde Estuary. Volume II. Model construction, evaluation and user manual. WRC Report no. 1679/2/o8. Pretoria: Water Research Commission.

Turpie JK, Clark BM, Hutchings K. 2007. The economic value of marine protected areas along the Garden Route coast, South Africa, and implications of changes in size and management. Report to WWF South Africa. Cape Town: Anchor Environmental Consultants.

Turpie JK, de Wet J. 2009. The recreational value of the Kogelberg Coast, South Africa, and implications of changes in management. Report to WWF South Africa. Cape Town: Anchor Environmental Consultants.

Turpie JK, Heydenrych BJ, Lamberth SJ. 2003. Economic value of terrestrial and marine biodiversity in the Cape Floristic Region: implications for defining effective and socially optimal conservation strategies. Biological Conservation 112: 233-251.

Turpie JK, Hosking S (eds). 2005. Proceedings of a national workshop on resource economics as a tool for the management and conservation of estuaries in South Africa; 10-11 March 2005, Velddrif, South Africa. Cape Town: Anchor Environmental Consultants.

Turpie JK, Savy C, Clark B, Atkinson L. 2005. Boat-based whale watching in South Africa: an economic perspective. Report to Department of Environmental Affairs and Tourism: Marine and Coastal Management. Cape Town: Anchor Environmental Consultants.

Van der Krogt P. 2012. Fisheries, livelihoods and governance. A case study of migratory line fishermen in the Struisbaai, South Africa. MSc thesis, University of Amsterdam, Netherlands.

van Sittert L. 1993a. "More in the breach than in the observance:" crayfish, conservation \& capitalism c.1890-c.1939. Environmental History Review 17: 20-46.

van Sittert L. 1993b. 'Making like America': the industrialisation of the St Helena Bay fisheries c. 1936-c. 1956. Journal of Southern African Studies 19: 422-446.

van Sittert L. 2002. Those who cannot remember the past are condemned to repeat it: comparing fisheries reforms in South Africa. Marine Policy 26: 295-305.

van Sittert L. 2003. The tyranny of the past: why local histories matter in the South African fisheries. Ocean \& Coastal Management 46: 199-219.

van Sittert L, Branch G, Hauck M, Sowman M. 2006. Benchmarking the first decade of postapartheid fisheries reform in South Africa. Marine Policy 30: 96-110.

van Wyk J. 2007. The impact of development on the environment as part and parcel of integrated development planning? Law, Democracy and Development 11: 57-79.

van Zyl M. 2008. Heritage and change: the implementation of fishing policy in Kassiesbaai, South Africa. MSocSc thesis, University of Cape Town, South Africa.

van Zyl M. 2009. Ocean, time and value: speaking about the sea in Kassiesbaai. Anthropology Southern Africa 32: 48-58. 
Whatmore SJ. 2009. Mapping knowledge controversies: science, democracy and the redistribution of expertise. Progress in Human Geography 33: 587-598.

Witbooi E. 2006. Law and fisheries reform: legislative and policy developments in South African fisheries over the decade 1994-2004. Marine Policy 30: 30-42.

Worden N. 1994. Unwrapping history at the Cape Town Waterfront. The Public Historian 16: 33-50.

Worden N. 1996. Contested heritage at the Cape Town Waterfront. International Journal of Heritage Studies 2: 59-75. 